MT-DP - 2016/27

\title{
Frontloading the Unemployment Benefit: An Empirical Assessment
}

\author{
ATTILA LINDNER - BALÁZS REIZER
}




\title{
Discussion papers \\ MT-DP - 2016/27
}

Institute of Economics, Centre for Economic and Regional Studies, Hungarian Academy of Sciences

KTI/IE Discussion Papers are circulated to promote discussion and provoque comments. Any references to discussion papers should clearly state that the paper is preliminary.

Materials published in this series may subject to further publication.

Frontloading the Unemployment Benefit: An Empirical Assessment

Authors:

\author{
Attila Lindner \\ University College London, IZA, IFS \\ and Institute of Economics, Centre for Economic and Regional Studies, \\ Hungarian Academy of Sciences \\ e-mail: a.lindner@ucl.ac.uk \\ Balázs Reizer \\ junior research fellow \\ Institute of Economics, Centre for Economic and Regional Studies, \\ Hungarian Academy of Sciences \\ $\mathrm{PhD}$ student at the Central European University \\ e-mail: reizer.balazs@krtk.mta.hu
}

August 2016

ISBN 978-615-5594-66-3

ISSN $1785377 \mathrm{X}$ 


\title{
Frontloading the Unemployment Benefit: An Empirical Assessment
}

\author{
Attila Lindner - Balázs Reizer
}

\begin{abstract}
In November 2005, the Hungarian government frontloaded the unemployment benefit path, while kept constant the total benefit amount that could be collected over the unemployment spell. We estimate the effect of this reform on non-employment duration using an interrupted time series design. We find that non-employment duration fell by 1.5 weeks after November 2005, while reemployment wages and the duration of new jobs remained the same. We show that the decrease in non-employment duration was large enough to make the benefit reform revenue neutral. Our welfare evaluation for this reform is positive: frontloading increased job finding, it made some of the unemployed better off, and did not cost anything to the taxpayers.
\end{abstract}

JEL: H20, J64

Keywords: unemployment, declining unemployment benefits, welfare analysis

\section{Acknowledgement}

We would like to thank Lajos Bódis, David Card, Hedvig Horváth, Gábor Kézdi, Patrick Kline, Mihály Szoboszlai, Emmanuel Saez, Owen Zidar and the audiences of UC Berkeley, Central European University, the conference at Szirák, 4th Seek conference at Mannheim. We are grateful for János Köllő, Kitti Varadovics, Mónika Bálint, Dániel Biró for giving us access to the administrative data and providing continuous help throughout the project and to Csaba Nagy and Zsolt Pelek for explaining the practical implementation of the reform. We gratefully acknowledge the support of Firms, Strategy and Performance Lendület Grant of the Hungarian Academy of Sciences. 


\title{
A munkanélküli segély átütemezésének hatásai
}

\author{
Lindner Attila - Reizer Balázs
}

\section{Összefoglaló}

2005 novemberében jelentôsen megváltoztak a munkanélküli segély kifizetésével kapcsolatos szabályok. A korábbi havi fix segélyt egy időben csökkenő segélypálya váltotta fel, miközben a teljes jogosultsági idő alatt megszerezhető segély összege nem változott. Dolgozatunkban azt vizsgáljuk, hogy milyen hatással volt ez a reform a munkanélküliség hosszára. Eredményeink szerint a munkanélküliség átlagos hossza 1,5 hetet csökkent a reform után, míg az új munkahelyen elöltött idő és az új elhelyezkedés utáni bérek nem változtak. Végül bemutatjuk, hogy a gyorsabb elhelyezkedés elegendő volt ahhoz, hogy ellensúlyozza a bőkezúbb járadékszabályok okozta költségvetési kiadásnövekedést. Értékelésünk szerint a reform növelte a társadalmi jólétet, mivel a munkanélküliek anyagilag jobban jártak és hamarabb elhelyezkedtek a reform után, miközben nem növekedett a munkanélküli segélyek erőforrásigénye.

Tárgyszavak: munkanélküliség, időben csökkenő munkanélküli segély, jóléti elemzés JEL kódok: H20, J64 


\title{
Frontloading the Unemployment Benefit: An Empirical Assessment
}

7th July 2016

\author{
Attila Lindner ${ }^{\S}$ \\ University College London, \\ CERS-HAS, IZA, IFS
}

\author{
Balázs Reizer $§ \S$ \\ Central European University, \\ CERS-HAS
}

\begin{abstract}
In November 2005, the Hungarian government frontloaded the unemployment benefit path, while kept constant the total benefit amount that could be collected over the unemployment spell. We estimate the effect of this reform on non-employment duration using an interrupted time series design. We find that non-employment duration fell by 1.5 weeks after November 2005 , while reemployment wages and the duration of new jobs remained the same. We show that the decrease in non-employment duration was large enough to make the benefit reform revenue neutral. Our welfare evaluation for this reform is positive: frontloading increased job finding, it made some of the unemployed better off, and did not cost anything to the taxpayers.
\end{abstract}

*We would like to thank Lajos Bódis, David Card, Hedvig Horváth, Gábor Kézdi, Patrick Kline, Mihály Szoboszlai, Emmanuel Saez, Owen Zidar and the audiences of UC Berkeley, Central European University, the conference at Szirák, 4th Seek conference at Mannheim. We are grateful for János Kölló, Kitti Varadovics, Mónika Bálint, Dániel Biró for giving us access to the administrative data and providing continuous help throughout the project and to Csaba Nagy and Zsolt Pelek for explaining the practical implementation of the reform. We gratefully acknowledge the support of Firms, Strategy and Performance Lendület Grant of the Hungarian Academy of Sciences

$\S$ a.lindner@ucl.ac.uk, ${ }^{\S}$ reizer_balazs@phd.ceu.edu 


\section{Introduction}

Unemployment insurance programs aim to protect against financial distress at job loss and to maintain incentives to search for jobs. Unfortunately, these two goals are often in conflict: an insurance that provides better protection often leads to moral hazard and, as a result, to longer unemployment duration. This classic trade-off between insurance value and moral hazard determines the optimal level of the unemployment benefit (Baily, 1978; Chetty, 2008).

However, the classic analysis of optimal unemployment insurance (UI) assumes that the benefit is constant throughout the unemployment spell. Changing the benefit path, in principe, can maintain the insurance aspects of UI and can provide more incentives to search for a job at the same time. For instance, consider a change that frontloads the benefit profile by raising

the unemployment benefit with $\$ 1$ in the first period and by cutting it with $\$ 1$ in the second period. Under this benefit change, the short-term unemployed can collect more benefits, while the long-term unemployed collect the same amount of benefit throughout their unemployment spell. Therefore, benefit frontloading makes none of the unemployed worse off and makes some off them better off.

The potential downside effect of such a policy change is that the total revenue of the UI system might increase. Such an increase in costs would eventually increase taxes and make taxpayers worse off. However, the effect of frontloading on government spending is ambiguous. On the one hand, the cost of UI increases mechanically as some of the unemployed collect more benefits. On the other hand, frontloading might speed up the transition to employment which leads to less benefit pay-outs and more tax revenues. In fact, this behavioral response can be large enough to fully offset the mechanical cost increase caused by benefit frontloading. 
Therefore, the benefit frontloading described here can lead to a win-win situation where some of the unemployed are made better off without making any other actors worse off. However, it remains an empirical question whether the cost savings caused by the behavioral responses is large enough to offset the mechanical cost increase induced by the reform. This paper provides the first empirical assessment to answer this question. We exploit a unique Hungarian reform that changed radically the time profile of UI payments (see Figure 1). The unemployed who claimed benefit before 1st of November 2005 could rely on a constant benefit for 270 days. However, those who claimed benefit after November 1st were eligible to the same benefit amount, but in a different structure: they had higher benefit in the first 90 days and then lower in the next 180 days. Putting it simply, the Hungarian UI reform frontloaded the benefit profile while the total benefit that could be collected remained the same.

We assess the effect of this unique policy change on non-employment duration using administrative data on UI claimants and social security contributions. Our main empirical strategy compares non-employment durations for those who claimed benefit before the UI change,and were, therefore, left with the old benefit schedule, to those who claimed afterwards. We implement an interrupted time series analysis and show that the average non-employment duration was stable preceding the reform, while there was a sharp drop in non-employment duration that coincides with the timing of the reform. We estimate that non-employment duration decreased by 10 days, or 1.5 weeks after the reform.

We also examine the effect of the benefit change on the quality of jobs found. We do not find any evidence for a change in reemployment wages or in the duration of new jobs. Therefore, our estimates suggest that the shortened unemployment duration did not lead workers to accept worse (or better) jobs. 
We then we translate the estimated effects into changes in the UI budget (Table 6). The new benefit mechanically increased governmental spending, because short-term unemployed collected more benefits. However, it also fastened up job finding, which decreased spending on unemployment benefits. These effects offset around $50 \%$ of the mechanical cost increase. Another offsetting channel is the increase in personal income tax and social security contributions. This latter offset another $70 \%$ of the mechanical cost increases, and so the behavioral responses were large enough to counterbalance the mechanical cost increase caused by the reform.

Our estimates allow us to examine the welfare implications of the reform. The benefit frontloading made the short-term unemployed better off as they were able to collect more benefits after the reform. Moreover, long-term unemployed have collected the same amount benefit throughout the unemployment spelland, as a result, they were able to consume the same as before. ${ }^{1}$ Therefore, no unemployed was made worse off by this reform, and many of them was made better off.

Our estimates also imply that the burden on taxpayers did not increase after the reform. This is because the extra benefit collected by the unemployed was offset by the benefit savings and extra taxes paid as a result of the shorter unemployment spells. Moreover, the unemployed did not accept lower paying or less stable jobs. Therefore, the evidence presented here shows that benefit frontloading was a win-win policy: both the unemployed and the employed were made better off byreceiving more generous unemployment benefit schedule but in a structure that reduced moral hazard. Therefore, the Hungarian UI reform was a Pareto improving policy change.

The key assumption behind our empirical strategy is that there were no other policy or economic

\footnotetext{
${ }^{1}$ Unemployed in the new system can replicate the old consumption profile by saving some of the extra dollars they got at the beginning of their unemployment spell. However, even if the unemployed can not save, they are better off as long as the pre-reform benefit was constant throughout the unemployment spell. Moreover, it is easy to show that hand-to-mouth unemployed are also better off in that case.
} 
changes that could explain the sharp drop in non-employment duration after the reform The aggregate unemployment rate was stable in this period and the composition of the unemployed who claimed benefit was similar before and after the reform suggesting that economic changes cannot explain the change in non-employment duration. The only important policy change that could affect our results is a voulantary reemployment bonus scheme (RB), which was introduced parallel with the benefit reform.

To separate the effect of the reemployment bonus scheme from benefit frontloading, we exploit the local variation in knowledge about the availability of the new bonus scheme similarly to Chetty et al. (2013). While UI offices provided clear and straightforward information to all newly unemployed about the level and the timing of their benefit, the availability ofthe reemployment bonus scheme was less salient. Moreover, the reemployment bonus scheme was quite complicated and it was also associated with substantial hassle costs. Therefore, the role of local UI offices was crucial to advocate the scheme.

We infer the unemployed access to information from the average bonus take-up rate at the local UI office where the benefit was claimed. There are a large and persistent differences in take-up rates across UI offices that are not related to observable characteristics of the unemployed. In some locations the take-up rate was close to zero, while in others it went above $10 \%$. We show that the size of the drop in non-employment duration after the reform was very similar in zero or very low take-up and high take-up locations. This suggest that access to information on the voluntary RB scheme is unlikely to have had any significant effect on non-employment duration.

This paper is related to the literature on estimating moral hazard implications of unemployment insurance. Numerous studies scrutinized the effect of changing the benefit level (e.g. Meyer 1990; Lalive et al. 2006; Landais 2015; Card et al. 2007) and most papers found that there is a 
considerable effect of unemployment benefits on job search behavior (see a survey of this literature by Krueger and Meyer 2002; Chetty and Finkelstein 2013). Other aspects of unemployment insurance systems have been examined, such as reemployment bonuses (Van der Klaauw and Van Ours, 2013) and enforcement (Van den Berg and Van der Klaauw, 2006; Cockx and Picchio, 2013). However, the empirical evidence on the effect of changing the benefit path is surprisingly limited. A notable exception is Kolsrud et al. (2015), who empirically estimate the moral hazard costs of unemployment benefits paid at different times during the unemployment spell. They find that the unemployed respond more to benefit changes at the beginning of the UI spell than towards the end. Our results imply the opposite: the effect of increasing the benefit at the beginning has a smaller effect than the decrease later on. One possible explanation for this discrepancy is that the reform in Hungary is more radical and more salient than the one analyzed in Kolsrud et al. (2015) In our setup, therefore, the unemployed are more likely to be aware of future drops in their benefits and so they will respond more to them.

Our results also contribute to the extensive theoretical literature on the optimal time profile of unemployment insurance (e.g. Shavell and Weiss 1979; Hopenhayn and Nicolini 1997; Cahuc and Lehmann 2000; Werning 2002; Shimer and Werning 2008). These papers derive the fully optimal UI profile but they need to make strong assumptions about the environment in which the unemployed make their decisions (e.g. borrowing constraints). It turns out that the optimal UI profile is very sensitive to these assumptions (Hopenhayn and Nicolini, 1997; Werning, 2002). Moreover, the fully optimal benefit schedule is often quite complicated and hard to implement. Therefore, instead of searching for the fully optimal UI benefit schedule, we look at the welfare implication of an easily implementable reform that moves away from the standard constant benefit schedule to a frontloaded one. Our approach will not come up with the first-best benefit profile, 
but may help to inform policy makers as to which direction they should deviate in order to find it.

We also contribute to the effect of unemployment insurance on job quality. Recent research finds mixed results on the UI wage effect (Schmieder et al., 2013; Nekoei and Weber, 2015). Similarly to Lalive (2007) and Van Ours and Vodopivec (2008) we do not find a significant relationship between the length of unemployment and reemployment wages.

The paper is set out as follows. Section 2 describes the data and institutional details of our unemployment insurance reform. Section 3 presents the empirical results. In Section 4 we use our empirical estimates to assess the welfare implications of reform. Section 5 concludes.

\section{Institutional Background and Data}

\subsection{The Benefit Reform in Hungary}

Hungary had a two-tier unemployment insurance system around 2005. In the first tier the unemployment benefit depended on the length and amount of contributions ${ }^{2}$. After exhausting the first tier, the unemployed were eligible for unemployment assistance. The amount of the benefit in the second tier was the same for all unemployed and the length of it depended on the age of the UI claimants. After both tiers were exhausted, the unemployed were eligible for welfare. However, welfare payments, unlike the UI benefit, depended on family income and it were lower than the unemployment benefit.

The UI reform in 2005 changed the benefit schedule dramatically in the first tier for those who claimed benefit after November 1st, 2005, while it kept unaffected the length of unemployment

\footnotetext{
${ }^{2}$ The length of eligibility was the number of working days in the last four years divided by 5 and it was capped at 270 days. The amount of the benefit was based on the average monthly taxable income in the last year before unemployment and it was also capped.
} 
benefit. In our analysis we concentrate on the unemployed who experienced a frontloaded benefit as a result of the reform. These unemployed are individuals who worked more or less uninterrupted in the preceding four years of their job loss and whose earnings base was above HUF108,000 (\$504) in 2005 (around the 70th percentile of UI claimants). Figure 1 summarizes the benefit path for this group before and after the reform. Unemployed individuals who claimed benefit before November 1st were eligible for HUF44,460 (\$222) for the first 270 days. As opposed to this, those who claimed benefit after November 1st got HUF68,400 (\$342) in the first 90 days and HUF34,200 (\$171) in the next 180 days. An important feature of the reform was that the total benefit that could be received throughout the unemployment spell remained approximately the same and only the timing of the benefit payouts changed.

Newly unemployed individuals who wished to collect unemployment benefits had to go the local UI office and attend a 30-minute session which explained their rights and obligations as a claimant. Then each individual received a personalized letter which characterized their benefit schedule in the first tier. Figure A-1 shows an example of the first page of such a letter for an unemployed individual who claimed benefit under the new rules. The benefits are highlighted in the table in the middle of the page, wherethe length of the disbursement period in days and the daily amount are shown. It is obvious that the benefit schedule was salient from the beginning of the unemployment spell.

There were two other changes that were implemented in 2005. First, unemployment assistance (UA- the second tier) was shortened from 180 days to 90 for those who claimed benefit after February 5th, 2005. Second, the government introduced a voluntary reemployment bonus (RB) scheme in parallel with the benefit reform. Under this new scheme, the unemployed who claimed benefit after November 1st, 2005 and found a job in the first 270 days could claim 50 percent of 
the remaining unemployment benefit as a lump sum. The take-up rate of the RB scheme was very low as only 6 percent of the unemployed took advantage of this new scheme. Claiming UI benefit had two important drawbacks. First, the default option was not to take up RB and if someone decided to make use of it, she had to go through a complicated administrative process ${ }^{3}$. Second, claiming $\mathrm{RB}$ also meant that the remaining benefit eligibility was lost. Therefore, RB claimants had to start to collect benefit eligibility from zero again, and this may have seemed a risky step to take for many newly employed worker on probation. In Section 3 we do a couple of robustness checks to show that the changes in non-employment durations were unlikely to be driven by the shorter UA benefits in the second tier or by the voluntary RB scheme.

Finally, it is worth highlighting that the economy was growing at around $3-4 \%$ before the reform and a somewhat lower level afterwards (see Figure A-2 Panel a). Nevertheless, aggregate labor market conditions were not affected by the lower performance of the economy and aggregate unemployment was stable around the period of our analysis (see Figure A-2 Panel b). ${ }^{4}$

\subsection{Database and sample definition}

We observe a 50 percent random sample of the unemployed registered at the Hungarian National Employment Service between January 2004 and $2008^{5}$. During this time period we have information on the amount to which one is eligible and the starting and ending date of unemployment benefit spells. We also observe employment history and the earnings from social security contri-

\footnotetext{
${ }^{3} \mathrm{RB}$ could only be claimed in person at the local unemployment office when 270 days elapsed after the benefit claim. Moreover, the employment status had to be continuous between the reemployment and the RB claim.

${ }^{4}$ The lower GDP growth rate would predict that non-employment duration is higher after the reform. However, in Section 3 we show that the average length of employment was in fact lower after the reform. Therefore, if the change in GDP had some effect on our results, then we are likely to underestimate the "true" effect of the reform.

${ }^{5}$ The sample includes individuals who were born every second day after January 1st, 1927.
} 
butions between 2002 and 2008.

We restrict attention to prime age workers (25-49 years) who had 270 days benefit eligibility. To analyze the effect of the reform, we compare the average length of benefit duration before and after the reform. As figure Figure 1 shows, the before group consists of the unemployed who claimed benefit between 15th November 2004 and 15th October 2005. We leave out workers who claimed benefit around 1st of November to make sure we do not include in the analysis workers who postponed their benefit claims in order to get into the new system. In any case, the number of claimants around November 1st is not unusual relative to previous years, which indicates that most of the unemployed did not manipulate their claiming date because of the reform.

The after group is made up by the unemployed who claimed benefit between November 15th, 2005 and October 15th, 2006. By using this sample definition, the before and the after group consists ofthe same months of the year, so seasonality does not confound our results.

The basic descriptive statistics are shown in Table 1. We observe approximately 7500 unemployed both before and after the reform. The observable characteristics of the two groups are very similar. The share of women and the average year of education is slightly larger in the after sample but the average income before unemployment was the same in both groups. The average time spent between job loss and benefit claim was 31 days both before and after the reform, which indicates that people who lost their jobs before the reform did not postpone their benefit claim to become eligible for the new benefit schedule. Finally, less than 6 percent of the unemployed claimed reemployment bonus. 


\section{Results}

In this section we evaluate the impact of the reform on non-employment duration and on the quality of jobs found. Figure 4 shows the Kaplan-Meier survivor rate for those who claimed benefit before (between November 15th, 2004 and October 15th, 2005) and after the reform (between November 15th, 2005 and October 15th, 2006). In the first 90 days, the two job survivor functions are very similar. After 3 months the job finding rate of the after group rises compared to the before group. As a result, a significantly higher share of workers finds a job during the first 270 days after the reform than before the reform.

To estimate the effect of the reform on the length of unemployment, we estimate the following regression:

$$
\text { NonEmpDur }_{i}=\alpha+\beta a \text { fter }_{i}+\gamma X_{i}+\varepsilon_{i}
$$

where the dependent variable shows the time elapsed between benefit claim and re-employment. We cap the length of unemployment at 270 days because the reform affected the benefit eligibility only in the first 270 days. However, capping at a higher level does not substantially change the results. The main variable of interest is the after $_{i}$ dummy which indicates whether the unemployed individual claimed benefit after the reform. $X_{i}$ denotes the control variables that include age, age square, years of education and its square, log income in 2002, log income in 2003, sex, dummies that control for the day of the month the benefit was claimed, one digit occupation and location dummies.

Table 2 summarizes the main findings of the paper. According to Column 1, the length of non-employment decreased by 10.46 (s.e. 2.11) days after the reform. In Column 2 we take into 
account the fact that the characteristics of UI claimants differ slightly before and after the reform. The results show that the decline in duration is even bigger now: 11.28 (s.e. 2.10) days. In Column 3 we also control for the location where the benefit was claimed. The estimated effect of the reform is 12.18 (s.e. 2.90) in that case.

As robustness check for the functional form we also estimate the effect of the reform using the Cox proportional hazard model:

$$
h_{d}=\delta_{d} \exp (\lambda a f t e r+\kappa X)
$$

where $h_{d}$ denotes the re-employment hazard $d$ days after the benefit has been claimed, $\delta_{d}$ is an unrestricted day effect (baseline hazard), and the control variables, $X$, are the same as in equation 1. The Cox hazard model shows similar effects. According to the right panel of Table 2, the reemployment hazard increased with 4-6 percent after the reform and the inclusion of control variables do not significantly alter the point estimates.

Our estimates indicate that after the reform, non-employment duration was lower by 10-12 days. Figure 3 panel (a) plots the average length of non-employment by six month periods relative to the benefit change. The gap shows that non-employment duration was around 197 days in the preceding 6 month periods and that has been dropped to 187 days immediately after the reform. In Figure 3 panel (b) we show the average non-employment duration after controlling for observables and location fixed effects. Again the the change in non-employment duration is very much coincided with the implementation of the new benefit schedule. The figures also highlight that the average length of non-employment was very similar in the last 18 month before the reform. 
Therefore, the change in the second tier after February 5th, 2005 had at most a small effect on non-employment duration. Given that the benefit level in the second tier is quite low (HUF22, 800 or $\$ 114$ per month) this is not surprising.

Did the faster reemployment hurt job quality? To answer this question we analyze other outcomes besides the non-employment. duration. For example worker may accept a less stable job after the reform to exit unemployment earlier (Jarosch, 2014). In Table 3 Column (1) to (3) we estimate equation 1, where the outcome variable is the tenure at the new job. All columns show a negative effect on job tenure, but the estimated effects (e.g. less than 1,5 days in Column 3) are negligible in statistical and economic sense. The lack of effect on job tenure at the new job has been also confirmed in Figure 5 where we plot the average tenure by six month periods relative to the benefit change (in Panel a without controls in Panel b with controlling for observables and UI location fixed effects).

Figure 6 shows that frontloading did not affect the reemployment wages either ${ }^{6}$. We plot the log-ratio of the reemployment wage and the unemployment benefit base wage by six month periods. $^{7}$ We control for a linear time trend to rule out the effect of the inflation and economic growth. The figure shows that the average reemployment monthly wage is 46-48 log-point lower ${ }^{8}$ As the unemployment benefit base wage calculated based on the average earnings in the last four years, this measure overestimates the income loss after unemployment (Card et al., 2007; Schmieder

\footnotetext{
${ }^{6}$ We calculate the daily reemployment wage from the social security data by dividing the monthly earnings by the number of days worked in that month.

${ }^{7}$ The unemployment benefit base wage was calculated by the unemployment insurance office based on the average (daily) wage in the last four years. The unemployment benefit base wage was not affected by severance payment, which was 1 to 6 months' salary depending on the tenure. The average daily wage calculated from the social security data also include severance payments. This means that the log-ratio of the reemployment wage and the wage in the last job overestimates the true wage loss for those who received severance payments.

${ }^{8}$ This difference is equivalent to a 37 percent decrease.
} 
et al., 2013). In any case, Figure 6 highlights that reemployment wages are not affected around the time of the unemployment benefit reform.

Table 4 reports the point estimates for the log-ratio of the reemployment wage and the base wage. According to Column 1, the reemployment wage ratio was 1.6 (s.e. 2.1) percentage point larger after the reform, but the raise was not significant. The effect on reemployment wage is slightly higher, 2.7 (s.e. 1.7) once we control for observable characteristics of the unemployed and the location fixed effects. While these point estimates are significant in economic terms, we should be cautious in drawing strong conclusions. First, none of these estimates are statistically significant at the conventional levels. Moreover, as it has been shown in Figure 6, the timing of the increase in reemployment wages does not perfectly align with the implementation of the reform.

In Table 4 Column 4-9 we also explore alternative definitions of reemployment wages. Results with log-ratio of the reemployment wage and the wage in the last job are shown in Column 4-6. The results are slightly different relative to the results in Column 1-3 as the point estimates are near zero here. However, the wage in the last job is also is affected by severance payments, and so these estimate might be biased. Therefore, in Columns (7) to (9) we show the results for logratio of reemployment wage and the average wage in 2002. The point estimate is again around 2 percentage points and statistically insignificant.

Overall, these results suggest that the effect on reemployment wages might be positive or zero, but it is unlikely to be negative. Therefore, we find no evidence that the reform hurt job quality.

Can reemployment bonus explain the decrease in non-employment duration? As we discussed in the previous section, those who claimed benefit after November 1st, 2005 was not only faced with the frontloaded benefit schedule but were also eligible to claim voluntary reemployment bonus if they found a job within 270 days. The reemployment bonus was associated with substantial hassle 
costs and it was a less salient policy than the benefit frontloading. Still, it is possible that the parallel introduction of the reemployment bonus explains part of the decline in non-employment duration. To separate the effect of benefit frontloading from the reemployment bonus, we exploit the anecdotal evidence that at some local UI offices the reemployment bonus was advertised more by UI officials than at other ones. While we do not observe directly which UI offices have been more keen on advocating the reemployment bonus scheme, we use the local level take-up rate of the reemployment bonus as a proxy for information provided to the unemployed.

Two empirical observations motivate that the take-up rate is related to access to information and not to other factors. First, Figure 7 panel (b) shows a scatter plot between the take-up rate one year after the reform and the take-up rate 2 years after. The figure uncovers a strong correlation (0.64) between take-up rate in the two periods. Therefore, the take-up rate differences across locations are persistent. Second, and more importantly, Figure 8 shows scatter plots between different measures of the composition of the unemployed and the take-up rate by UI locations. Panel (a) measures the composition of the unemployed by the average pre-reform non-employment duration. We use the pre-reform non-employment duration and not the post-reform one, because the post-reform does not just measure the composition of the unemployed but the effect of the reemployment bonus as well. ${ }^{9}$ Figure ?? Panel (b) measures the composition of unemployed by the predicted non-employment duration for those who claim benefit after the reform. To get the predicted values we run a regression of non-employment duration on observable characteristics

\footnotetext{
${ }^{9}$ The measure of pre-reform non-employment duration is a good proxy of the post-reform composition of the unemployed if the composition is stable over time. The correlation in non-employment duration between 1 year before and 2 years before the reform is 0.31 . Moreover, with all the caveats of using post-reform non-employment duration to measure the composition of the unemployed, it is worth highlighting that there is no relationship between non-employment duration and reemployment bonus take-up rate in the post-reform sample (results available on request).
} 
(age, age square, years of education and its square, log income in 2002, log income in 2003, sex, dummies that control for the day UI claimed, one digit occupation) in the pre-reform sample and predict the average non-employment duration for the post-reform.

Both Panel (a) and Panel (b) in Figure ?? depicts the Kernel-weighted local polynomial smoothing to show the non-parametric relationship between composition and take-up rate. In both panels we see no relationship between these two variables if we abstract away from the few outliers with very high take-up rates. This indicates that the reemployment bonus take-up rate is persistently higher at some locations and the differences are not related to the composition of the unemployed. This empirical pattern across UI locations is what we would expect to emerge if the take-up rate was determined by the behavior of local UI officers and not some underlying economic factors.

The effect of reemployment bonus on non-employment duration is likely to vary by the access to information on the scheme. Similarly to Chetty et al. (2013), the variation in access to information across locations can be used to better understand how reemployment bonus affects our baseline results. To do that, we compare low take-up rate (limited information) and high take-up rate (more information) locations that experienced differences in non-employment duration. In particular, we estimate the following regression:

$$
\text { unemployment }_{i}=\beta_{1}+\beta_{2} \text { after }_{i}+\beta_{3} \text { high }_{i}+\beta_{4} \text { high }_{i} * \text { after }_{i}+\gamma X_{i}+\varepsilon_{i}
$$

where the dummy variable $h i g h_{i}$ takes the value of 1 if the location is in the top quarter (take-up rate is higher than 16.2\%) and 0 if the location is in the lowest quartile (take-up rate is lower than $4.9 \%$ ) with respect to the reemployment bonus take-up rate. While this is a common difference-in-difference type regression, our main parameter of interest is not $\beta_{4}$, namely the effect 
of reemployment bonus on non-employment duration, but $\beta_{1}$, the effect of the reform on nonemployment duration at locations with close to zero take-up rate and limited information access.

Table 5 Column (1) to (4) summarizes the estimation results. In Column (1) and (3) we saw the baseline results for the sample that includes the lowest and highest quartile locations with low reemployment bonus take-up rate. The point estimates are slightly lower here than in the baseline Table 2 (-8.65 vs. -10.46 in the specification with no control and -12.18 vs. -10.70 in the specification with control and location FEs) and the differences are not statistically significant. In Column (2) and (4) we show the results on the same sample but estimating equation 3 . The results show that the effect of the after dummy is virtually unaffected by controlling for high takeup and its interaction with the after dummy. Moreover, the effect of the interaction term is very small and always insignificant. This indicates that the effect of the reform does not vary by the reemployment bonus take-up rate.

In Figure 9 we plot the relationship between the before-after change in non-employment duration and take-up rate across locations. We also plot the Kernel-weighted local polynomial smoothing to show the non-parametric relationship between these two variables. The figure supports our regression results in Table 5: there is no relationship between the effect of the reform on non-employment duration and the take-up rate.

As a robustness check, we report the estimates using Cox proportional hazard models. The results are presented in Table 5 Column (1) to (4). The point estimates in Column (1) and (3) are considerably higher in this sample. However, Column (2) and (4) highlights that these higher effects are virtually unaffected by whether the high take-up rate and its interaction with the after dummy are included. Therefore, these results confirm again that the effect of the reform does not 
depend on the take-up rate. ${ }^{10}$

The results presented here underline that access to information (measured by variation in takeup rate) on the reemployment bonus does not affect the estimates in non-employment duration. This is not surprising given that the reemployment bonus scheme was a very complicated, nonsalient policy with some substantial drawbacks, such as losing the remaining benefit eligibility if claimed. Therefore, our estimates indicate the the effect of the reemployment bonus was negligible, and the approximtaley 10 days decrease in non-employment duration can be attributed to frontloading the benefit schedule.

\subsection{Effect of the Reform on the Budget}

Our results presented in the previous section indicate that non-employment duration decreased considerably as a results of the benefit frontloading. We use our estimates to understand the budget consequences of this reform. The total budget needed to finance the first 360 days of the unemployed can be summarized by the following equation:

$$
G=\sum_{t=1}^{360} b_{t} S_{t}+\sum_{t=1}^{360} \tau w\left(1-S_{t}\right)
$$

where $\tau$ is the tax rate, $w$ is the reemployment wage, and $b_{t}$ and $S_{t}$ is the benefit schedule and the survival rate $t$ days after unemployment benefit was claimed, respectively. We decompose the change in total budget into two components:

\footnotetext{
${ }^{10}$ As a further robustness check, in Appendix Figure A-1 we show that the results are robust to controlling directly for the share of workers who claimed reemployment bonus (and its interaction with the after dummy).
} 


$$
\begin{aligned}
& \Delta G=\left(\sum_{t=1}^{360} b_{t}^{\text {post }} S_{t}^{\text {post }}+\sum_{t=1}^{360} \tau w\left(1-S_{t}^{\text {post }}\right)\right)-\left(\sum_{t=1}^{360} b_{t}^{\text {pre }} S_{t}^{\text {pre }}+\sum_{t=1}^{360} \tau w\left(1-S_{t}^{\text {pre }}\right)\right) \\
& =\underbrace{\sum_{t=1}^{360} S_{t}^{\text {pre }}\left(b_{t}^{\text {post }}-b_{t}^{\text {pre }}\right)}+\underbrace{\sum_{t=1}^{T}\left(S_{t}^{\text {post }}-S_{t}^{\text {pre }}\right)\left(b_{t}^{\text {post }}+\tau w\right)} \\
& \text { mechanical UI spending increase UI spending decrease } \\
& \text { caused by the reform caused by behavioral responses }
\end{aligned}
$$

where $b_{t}^{\text {post }}$ and $b_{t}^{\text {pre }}$ are the daily pre- and post benefit shown on Figure 1 , while $S_{t}^{\text {post }}$ and $S_{t}^{\text {pre }}$ is the daily pre and post survival rate shown in Figure 4 . The first term in the decomposition shows that an unemployed individual who finds a job quickly collects more benefit under the new system and this mechanically increases the government spending on UI. The second term captures the budget consequences of the behavioral responses to the reform: due to faster reemployment, spending on UI decreases and tax revenues increase. It remains an empirical question whether the mechanical or the behavioral effect has a larger influence on the budget.

Table 6 summarizes the key effects of the reform on the budget. It shows that in the absence of behavioral responses, benefit frontloading would have increased mechanically benefit payments by $\$ 119$. However, benefit frontloading sped up reemployment, which decreased spending on UI benefits by $\$ 57$. Moreover, finding jobs earlier also lead to higher UI contributions, which is equivalent to an additional $\$ 8$. From the government point of view, revenues outside the UI budget should also be taken into account. The wage related taxes and contributions paid because the unemployed find jobs quicker increased the revenue of the budget with an additional $\$ 90$.

To sum up, the mechanical increase of UI expenditures were $\$ 119$ while the behavioral response of the unemployed improved the balance of the budget by $\$ 156$, which suggests that frontloading 
improved the budget by $\$ 36$ per unemployed. We also calculated the standard errors around these estimates by bootstrapping. ${ }^{11}$ While at the conventional confidence levels we cannot rule out that the effect of the reform on the UI budget is negative, our estimates indicate that it is unlikely that the reform had a negative effect on it. ${ }^{12}$

\section{Welfare Assessment}

Our estimates in the previous section can be used to assess the welfare implications of frontloading. We use the stylized job search model of Chetty (2008) and Kolsrud et al. (2015) to highlight the key channels through with benefit frontloading affect welfare.

\section{$4.1 \quad$ Set-up}

We consider a discrete time model of job search in which agents live for $T$ periods. The representative agent starts as unemployed and searches for jobs in each period. Employment is an absorbing state $^{13}$, and so once a job is found, the unemployed will be employed at wage $w$ for the rest of her life. ${ }^{14}$

In each periods agents make two decisions: they choose search intensity $s_{t}$ and consumption level $c_{t}$. Search intensity is costly and these costs are represented by $c\left(s_{t}\right)$. We assume that the cost function is convex, strictly increasing and twice differentiable. The value function of the employed

\footnotetext{
${ }^{11}$ We take 1000 random sample with replacement, then calculate the Kaplan-Meire survival rates and the implied UI budget.

${ }^{12}$ The p-value of a one-sided hypothesis test on whether the budget effect is negative is .14

${ }^{13}$ Relaxing this assumption complicates the calculation of the value of employment, but the main conclusions of this section are not affected.

${ }^{14}$ We assume that the change in benefit profile does not affect reemployment wages, which is confirmed by our empirical analysis in Section 3.
} 
if $t<T$ is

$$
V_{t}^{E}\left(A_{t}\right)=\max _{A_{t+1}} u\left(c_{t}^{e}\right)+v(G)+\delta V_{t+1}^{E}\left(A_{t+1}\right),
$$

where $\delta$ is the discount factor, and $V_{T}^{E}\left(A_{t}\right)=\max _{A_{t+1}} u\left(w+A_{T}\right)+v(G)$. The value of employment depends on private consumption, $u\left(c_{t}^{e}\right)$, and on the consumption of public goods $v(G)$. Both $u()$ and $v()$ are strictly increasing, concave, twice differentiable functions. Assets earn a return $r$ per period so that consumers face a per-period budget constraint $c_{t}^{e}=w+A_{t}-\frac{A_{t+1}}{1+r}$ and a borrowing constraint $A_{t} \geq L .{ }^{15}$

The value function of the unemployed if $t<T$ is

$$
V_{t}^{U}\left(A_{t}\right)=\max _{A_{t+1}, s_{t}} u\left(c_{t}^{u}\right)-c\left(s_{t}\right)+v(G)+\delta\left[s_{t} V_{t+1}^{E}\left(A_{t+1}\right)+\left(1-s_{t}\right) V_{t+1}^{U}\left(A_{t+1}\right)\right],
$$

where $c_{t}^{u}=b_{t}+A_{t}-\frac{A_{t+1}}{1+r}$ and $V_{T}^{U}\left(A_{t}\right)=u\left(b_{t}+A_{T}\right)++v(G)$. Again the value of employment depends on public and private consumption.

Spending on the unemployment insurance system depends on the fraction of agents that stay unemployed at period, $S_{t}$, and the benefit paid out to these workers, $b_{t}$. The total unemployment benefit payout equals $\sum_{t=1}^{T}\left(\frac{1}{1+r}\right)^{t} S_{t} b_{t}$. The tax that can be collected depends on the fraction of workers who are employed, $1-S_{t}$, and on the tax rate, $\tau^{16}$. Finally, the government spends $G$ on public goods and so the government deficit, $D$, is defined by the following formula:

\footnotetext{
${ }^{15}$ The presence of borrowing constraints does not affect our results.

${ }^{16}$ We also include also social security contributions in taxes, because the link between contributions and future benefits is very weak for most workers (Summers, 1998).
} 


$$
D=\sum_{t=1}^{T}\left(\frac{1}{1+r}\right)^{t} G+\sum_{t=1}^{T}\left(\frac{1}{1+r}\right)^{t} S_{t} b_{t}-\sum_{t=1}^{T}\left(\frac{1}{1+r}\right)^{t}\left(1-S_{t}\right) \tau w
$$

We assume that the deficit must be kept constant, and so more spending on unemployment insurance (while keeping constant the tax revenue), will decrease the amount of public goods provided in the economy.

The UI benefit was constant before November 1st, 2015 and so $b_{t}=b .{ }^{17}$ The Hungarian reform increased the benefit by $\widetilde{\triangle b}$ in the first $N$ periods and decreased by $\Delta b$ afterwards, while the total benefit that can be collected throughout the unemployment spell remained constant, formally,

$$
\sum_{k=0}^{N} \Delta b_{1}+\sum_{k=N+1}^{T} \Delta b_{2}=\sum_{k=1}^{T} \Delta b_{k}=0
$$

Notice that we require here that the total benefit is kept constant in nominal terms and not in present value terms. These two differ if the interest rate, $r$, is positive. We make this assumption to stick to the exact reform that occurred, however, the results are unaffected if the present value of the total benefit is kept constant instead.

\subsection{Welfare implications}

The value of unemployment at period 0 captures the expected utility of a newly unemployed agent. We examine the effect of benefit change on this measure to understand the welfare implications of frontloading.

\footnotetext{
${ }^{17}$ If the interest rate, $r$, is positive, then this benefit path is slightly declining in present value terms.
} 
Proposition 1. Suppose that the unemployment benefit is increased by $\widetilde{\triangle b}$ in the first $N$ periods and decreased by $\Delta b$ afterwards, while the total benefit that can be collected throughout the unemployment spell remained constant and so equation 5 applies.

Then the effect of benefit change on the value of unemployment at the beginning of the UI spell is determined by the following formula:

$$
\Delta V_{0}^{U}\left(A_{0}\right)=\underbrace{u^{\prime}\left(c_{0}^{u *}\right) \Delta b_{0}+\sum_{k=1}^{N} \delta^{k} \prod_{i=1}^{k}\left(1-s_{i}^{*}\right) u^{\prime}\left(c_{k}^{u *}\right) \Delta b_{k}}_{\begin{array}{c}
\text { welfare effect caused by } \\
\text { change in the benefit } \\
\geq 0
\end{array}} \underbrace{-\sum \delta^{k} v^{\prime}(G) \triangle G}_{\begin{array}{c}
\text { welfare effect caused by } \\
\text { change in public spending } \\
\vdots 0
\end{array}}
$$

The first part of this expression, welfare effect caused by change in the benefit, is always nonzero and it becomes positive if optimal search $s_{t}^{*}$ is positive for at least one period throughout the unemployment spell or if the interest rate, $r$, is positive. Moreover, the second part of this expression, the welfare effect caused by the change in public spending, can be positive, negative or zero depending on the sign of $\triangle G$. This $\triangle G$ is the following:

$$
\Delta G=\underbrace{\sum_{\text {caused by the reform }}}_{\begin{array}{c}
\sum_{t=1}\left(\frac{1}{1+r}\right)^{t} S_{t} \Delta b_{t} \\
\sum_{t=1}^{T}\left(\frac{1}{1+r}\right)^{t}
\end{array}}+\underbrace{\sum_{\text {caused by shorter UI spell }}^{\sum_{t=1}^{T}\left(\frac{1}{1+r}\right)^{t}}}_{\text {UI spending decrease }}+\underbrace{\sum_{\text {caused by finding job sooner }}^{T}}_{\text {increase in tax revenue }}
$$

Proposition 1 highlights that the benefit change induced by frontloading increases the welfare of the unemployed by increasing private consumption. This is because under the new UI benefit schedule the consumption profile under the old rules can be replicated by saving the benefit increase 
in the first $N$ periods and consuming them later. The new benefit schedule, therefore, must provide at least as high consumption utility as the old one, and as the proposition highlights, under some week conditions it will be strictly higher.

However, the new benefit schedule can increase the funding need of the UI system, which can lead to cutting back spending on public goods, $\triangle G$. In principe, lowering public goods can offset the welfare gain caused by the consumption increase of the unemployed, but this is not necessarily the case. Proposition 1 shows that the effect on public spending is ambiguous and determined by three different factors. First, benefit frontloading mechanically increases the spending on UI, because the unemployed individuals who find jobs relatively quickly collect more benefits under the new rule. Second, a sizable decline in non-employment duration decreases spending on UI benefits. Third, unemployed individuals who find jobs quicker pay more taxes and increase government revenue. While the first effect increases the cost of the unemployment insurance system, the latter two effects decrease it. It remains an empirical questions, therefore, which of these effects dominates.

The results in Section 3.1 calculate the change in $\triangle G$ and show that in the Hungarian case the behavioral responses were large enough to offset the mechanical cost increase in the UI. This implies that, in fact, $\triangle G$ in fact increased and not decreased after the reform. Therefore, the Hungarian benefit change was clearly welfare improving, because not only did it increase private consumption consumption of the unemployed, but it also saved some money for the government.

It is worth highlighting that the result presented in Proposition 1 is very robust to alternative modeling assumptions. The presence of borrowing limits, unobserved heterogeneity among the unemployed, or hand-to-mouth consumers do not influence the welfare implications presented here. 


\section{Conclusion}

This paperpresented the Hungarian unemployment benefit reform where a new frontloaded benefit path replaced the flat benefit system. The virtue of the reform was that the timing of the benefit was changed while the total amount of the benefit that could have been collected stayed constant. We provided evidence that benefit frontloading speeded up reemployment and did not increase the cost of the unemployment insurance system. This implies that the new benefit schedule made some unemployed definitely better off and none of them worse off. Moreover, given that the reform increased government revenue, we conclude here that the Hungarian reform was welfare increasing.

Our results are in stark contrast with Kolsrud et al. (2015), who conclude that increasing the benefit profile is likely to be welfare improving. The key difference between their findings and ours is that they find that the behavior response to a benefit change at the beginning of the UI spell does not differ substantially from benefit changes happening latter on. If this were true, we should have found that the benefit increase at the beginning of the UI offsets the effect of the benefit decrease that happened towards the end of the UI, and so the behavioral responses to frontloading should be limited. As we showed above, our results does not support this prediction. While more studies are needed to understand better the behavioral responses to a benefit change, the key advantage of our setup relative to Kolsrud et al. (2015) is that we analyze here a very transparent and radical change in the UI benefit that is likely to induce responses in job search even in the presence of some adjustment costs (Chetty et al., 2013).

Finally, while this paper aims to evaluate the welfare implication of this reform, , in a related paper DellaVigna et al. (2016) we exploit the same reform to evaluate competing job search models. In that paper we show that a behavioral search model does a better job explaining the hazard 
rate to employment than the standard search models in the literature. Both papershighlight the importance of the benefit path, and suggest that redesigning the UI systems can sometimes break the classic trade-off between moral hazard and insurance. 


\section{References}

Baily, M. N. (1978). Some aspects of optimal unemployment insurance. Journal of Public Economics 10(3), 379-402.

Cahuc, P. and E. Lehmann (2000). Should unemployment benefits decrease with the unemployment spell? Journal of Public Economics r7(1), 135-153.

Card, D., R. Chetty, and A. Weber (2007). Cash-on-hand and competing models of intertemporal behavior: New evidence from the labor market. Quarterly Journal of Economics 122(4).

Chetty, R. (2008). Moral hazard versus liquidity and optimal unemployment insurance. Journal of Political Economy, University of Chicago Press 116(2), 173-234.

Chetty, R. and A. Finkelstein (2013). Social insurance: Connecting theory to data. Handbook of Public Economics 5, 111.

Chetty, R., J. N. Friedman, and E. Saez (2013). Using differences in knowledge across neighborhoods to uncover the impacts of the eitc on earnings. American Economic Review 103(7), $2683-2721$.

Cockx, B. and M. Picchio (2013). Scarring effects of remaining unemployed for long-term unemployed school-leavers. Journal of the Royal Statistical Society: Series A (Statistics in Society) $176(4), 951-980$.

DellaVigna, S., A. Lindner, B. Reizer, and J. F. Schmieder (2016). Reference-dependent job search: Evidence from hungary. NBER Working Paper w2225\%. 
Hopenhayn, H. A. and J. P. Nicolini (1997). Optimal unemployment insurance. Journal of Political Economy 105(2), 412-438.

Jarosch, G. (2014). Searching for job security and the consequences of job loss. V University of Chicago, Job Market Paper.

Kolsrud, J., C. Landais, P. Nilsson, and J. Spinnewijn (2015). The optimal timing of unemployment benefits: Theory and evidence from sweden.

Krueger, A. B. and B. D. Meyer (2002). Labor supply effects of social insurance. Handbook of Public Economics 4, 2327-2392.

Lalive, R. (2007). Unemployment benefits, unemployment duration, and post-unemployment jobs: A regression discontinuity approach. The American Economic Review 97(2), 108-112.

Lalive, R., J. Van Ours, and J. Zweimüller (2006). How changes in financial incentives affect the duration of unemployment. The Review of Economic Studies 73(4), 1009-1038.

Landais, C. (2015). Assessing the welfare effects of unemployment benefits using the regression kink design. American Economic Journal: Economic Policy 7(4), 243-278.

Meyer, B. D. (1990). Unemployment insurance and unemployment spells. Econometrica 58(4), $757-782$.

Nekoei, A. and A. Weber (2015). Does extending unemployment benefits improve job quality?

Schmieder, J. F., T. von Wachter, and S. Bender (2013, December). The causal effect of unemployment duration on wages: Evidence from unemployment insurance extensions. Working Paper 19772, National Bureau of Economic Research. 
Shavell, S. and L. Weiss (1979). The optimal payment of unemployment insurance benefits over time. The Journal of Political Economy, 1347-1362.

Shimer, R. and I. Werning (2008). Liquidity and insurance for the unemployed. American Economic Review 98(5), 192-242.

Van den Berg, G. J. and B. Van der Klaauw (2006). Counseling and monitoring of unemployed workers: Theory and evidence from a controlled social experiment*. International Economic Review 47(3), 895-936.

Van der Klaauw, B. and J. C. Van Ours (2013). Carrot and stick: How re-employment bonuses and benefit sanctions affect exit rates from welfare. Journal of Applied Econometrics 28(2), $275-296$.

Van Ours, J. C. and M. Vodopivec (2008). Does reducing unemployment insurance generosity reduce job match quality? Journal of Public Economics 92(3), 684-695.

Werning, I. (2002). Optimal unemployment insurance with unobservable savings. University of Chicago and UTDT. 


\section{Tables}

Table 1: Descriptive Statistics: Comparing Means of Main Variables Pre- and Post UI Reform

\begin{tabular}{c|cccc} 
& before & after & diff & t-stat \\
\hline Percent Women & $40.37 \%$ & $44.70 \%$ & $4.33 \%$ & 5.43 \\
Age in Years & $(0.55 \%)$ & $(0.57 \%)$ & & \\
& 36.82 & 36.89 & 0.07 & 0.60 \\
$(0.08)$ & $(0.08)$ & & \\
Imputed Education (years) & 11.87 & 12.04 & 0.17 & 4.70 \\
(based on occupation in the last job) & $(0.02)$ & $(0.02)$ & & \\
Log earnings in 2002 & 11.08 & 11.12 & 0.04 & 1.04 \\
Log earnings in 2003 & $(0.02)$ & $(0.02)$ & & \\
Waiting period* & 11.29 & 11.31 & 0.02 & 0.48 \\
& $(0.02)$ & $(0.02)$ & & \\
Reemployment bonus claimed & 31.24 & 31.56 & 0.32 & 0.52 \\
Number of observations** & $(0.42)$ & $(0.44)$ & & \\
& $0.00 \%$ & $5.91 \%$ & 0.06 & 21.67 \\
& $(0 \%)$ & $(0.27 \%)$ & & \\
\hline \hline
\end{tabular}

* number of days between job loss and UI claim

$* *$ there are some missing values for log earnings in 2002, 2003, 2004. 
Table 2: Baseline results: Effect of the Reform on Non-Employment Duration

\begin{tabular}{lcccccc}
\hline \multirow{2}{*}{ VARIABLES } & $(1)$ & $(2)$ & $(3)$ & $(4)$ & $(5)$ & $(6)$ \\
\hline \multirow{2}{*}{ After } & $-10.46^{* * *}$ & $-11.28^{* * *}$ & $-12.18^{* * *}$ & $0.043^{* *}$ & $0.057^{* * *}$ & $0.064^{* * *}$ \\
& $(2.11)$ & $(2.09)$ & $(2.29)$ & $(0.020)$ & $(0.021)$ & $(0.025)$ \\
Controls & no & yes & yes & no & yes & yes \\
Location FE & no & no & yes & no & no & yes \\
Observations & 15,009 & 15,009 & 15,009 & 15,009 & 15,009 & 15,009 \\
R-squared & 0.002 & 0.042 & 0.063 & & & \\
\hline$* * * \mathrm{p}<0.01,{ }^{* *} \mathrm{p}<0.05, * \mathrm{p}<0.1$ & & & &
\end{tabular}

Note: This table shows the effect of the reform on non-employment duration. Column 1-3 estimate regression in equation 1. Column 4-6 estimate the Cox proportional hazard in equation 2. The non-employment duration is capped at 270 days in all columns. After is a dummy, which is 1 if the unemployed individual claimed benefit after the benefit reform (between November 15th, 2005 and October 15th, 2006). The control variables are sex, age, age square, waiting period (the number of days between job lost and UI claimed), the county of residence, day of the month UI claimed, education, occupation (1 digit) in the last job, log earnings in 2002 and 2003. The location fixed effects control for the local UI office where the unemployed individual claimed benefit. Standard errors in parentheses are clustered at the local UI office level. 
Table 3: Job Quality: Effect of the Reform on Job Tenure in the New Job

\begin{tabular}{lcccccc}
\hline & \multicolumn{3}{c}{ Average tenure in days (OLS) } & \multicolumn{3}{c}{ Separation hazards (Cox-estimation) } \\
VARIABLES & $(1)$ & $(2)$ & $(3)$ & $(4)$ & $(5)$ & $(6)$ \\
\hline \multirow{2}{*}{ After } & -0.58 & -1.03 & -1.03 & 0.003 & 0.039 & 0.037 \\
& $(1.78)$ & $(1.79)$ & $(2.00)$ & $(0.036)$ & $(0.037)$ & $(0.042)$ \\
Controls & no & yes & yes & no & yes & yes \\
Location FE & no & no & yes & no & no & yes \\
Observations & 9,181 & 9,181 & 9,181 & 9,181 & 9,181 & 9,181 \\
R-squared & 0.000 & 0.017 & 0.045 & & & \\
\hline$* * * \mathrm{p}<0.01, * *$ & $\mathrm{p}<0.05, * \mathrm{p}<0.1$ & & & &
\end{tabular}

Note: This table shows the effect of the reform on the duration of the new job (measured in days). Column 1-3 estimate regression in equation 1 and Column 4-6 estimate the regression in 2 using the job tenure upon reemployment. Only workers who found a job within 360 days are included in the sample. The tenure is capped at 360 days in all columns. After is a dummy, which is 1 if the unemployed individual claimed benefit after the benefit reform (between November 15th, 2005 and October 15th, 2006). The control variables are sex, age, age square, waiting period (the number of days between job lost and UI claimed), the county of residence, day of the month UI claimed, education, occupation (1 digit) in the last job, log earnings in 2002 and 2003 . The location fixed effects control for the local UI office where the unemployed individual claimed benefit. Standard errors in parentheses are clustered at the local UI office level.. 


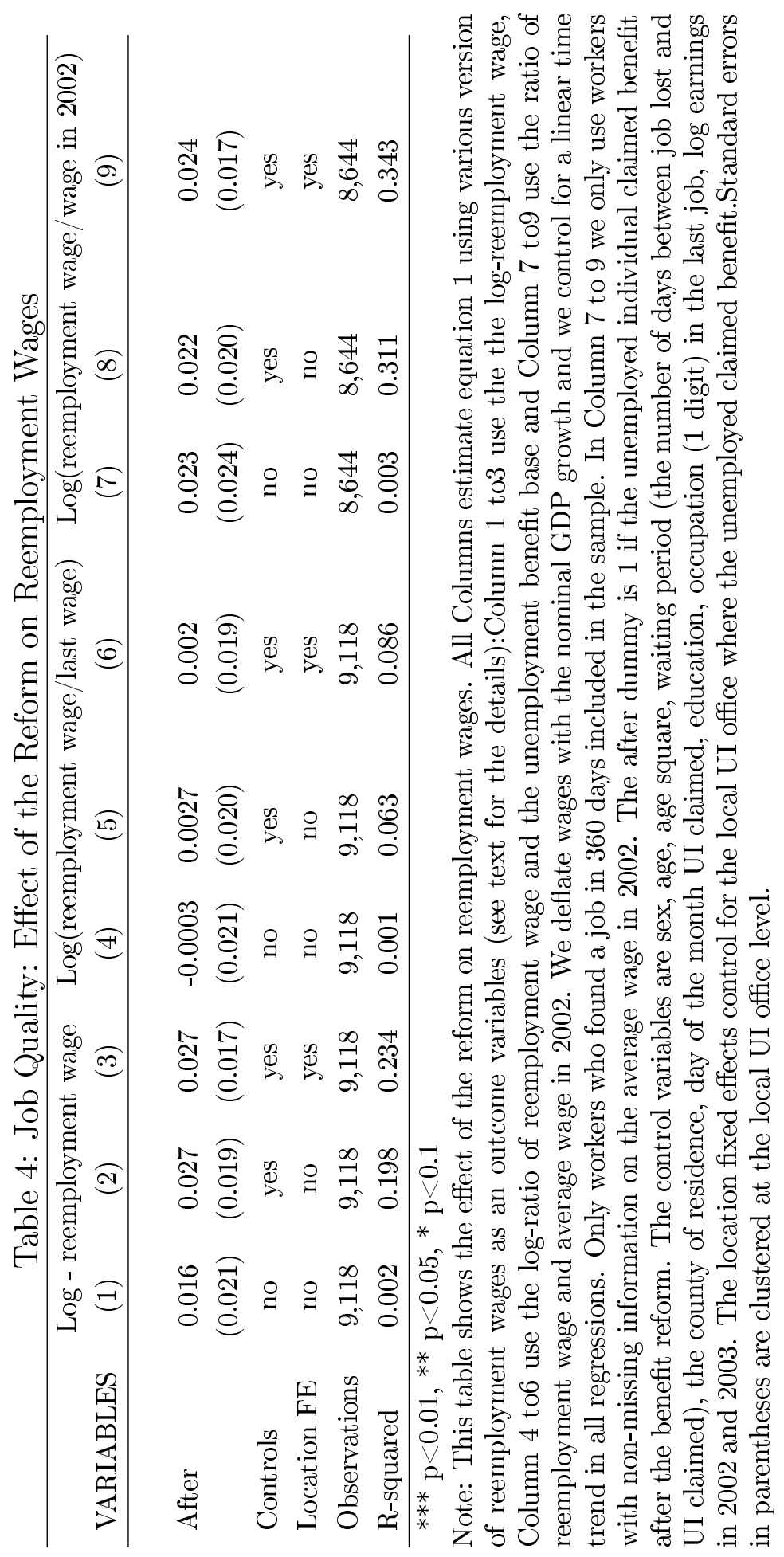


Table 5: The effect of Frontloading by the Reemployment Bonus Take-up Rate

\begin{tabular}{|c|c|c|c|c|c|c|c|c|}
\hline \multirow[b]{2}{*}{ VARIABLES } & \multicolumn{4}{|c|}{ Non-employment duration (OLS) } & \multicolumn{4}{|c|}{ Reemployment hazards (Cox-estimation) } \\
\hline & (1) & $(2)$ & $(3)$ & (4) & $(5)$ & (6) & (7) & (8) \\
\hline after & $\begin{array}{c}-8.65^{* * *} \\
(1.85)\end{array}$ & $\begin{array}{c}-8.20^{* * *} \\
(2.74)\end{array}$ & $\begin{array}{c}-10.70^{* * *} \\
(1.88)\end{array}$ & $\begin{array}{c}-10.01^{* * *} \\
(2.77)\end{array}$ & $\begin{array}{c}0.119^{* * *} \\
(0.033)\end{array}$ & $\begin{array}{c}0.107^{* *} \\
(0.047)\end{array}$ & $\begin{array}{c}0.151^{* * *} \\
(0.030)\end{array}$ & $\begin{array}{c}0.129 * * * \\
(0.042)\end{array}$ \\
\hline high take-up & & $\begin{array}{c}2.30 \\
(4.30)\end{array}$ & & & & $\begin{array}{l}-0.032 \\
(0.047)\end{array}$ & & \\
\hline high take-up*after & & $\begin{array}{l}-0.85 \\
(3.70)\end{array}$ & & $\begin{array}{l}-1.36 \\
(3.70)\end{array}$ & & $\begin{array}{c}0.023 \\
(0.066)\end{array}$ & & $\begin{array}{c}0.044 \\
(0.058)\end{array}$ \\
\hline controls & no & no & yes & yes & no & no & yes & yes \\
\hline location FE & no & no & yes & yes & no & no & yes & yes \\
\hline Observations & 7,217 & 7,217 & 7,217 & 7,217 & 7,217 & 7,217 & 7,217 & 7,217 \\
\hline R-squared & 0.002 & 0.002 & 0.064 & 0.064 & & & & \\
\hline
\end{tabular}

Note: This table shows the effect of the reform on non-employment duration by the local reemployment bonus take-up rate. The sample in all columns includes unemployed who claim benefit in the UI locations with the lowest quartile take-up rate and in the UI locations with the highest quartile take-up rate. Column 1,3,5 and 7 show the baseline results for this partiuclar sample. Column 2 and 4 estimate equation 3 and Column 6 and 8 the estimate a Cox proportinal hazard model. The length of non-employment is capped at 270 days in all Columns. The after dummy is 1 if the unemployed claimed benefit after the benefit reform. The high take-up is a dummy denoting that the unemployed claimed benefit at a location withhighest quartile reemployment bonus take up The control variables are sex, age, age square, waiting period (the number of days between job lost and UI claimed), the county of residence, day of the month UI claimed, education, occupation (1 digit) in the last job, log earnings in 2002 and 2003. The location fixed effects control for the local UI office where the unemployed claimed benefit. Standard errors in parentheses are clustered at the local UI office level. 
Table 6: The Effect of the Reform on the Budget

\begin{tabular}{|c|c|c|}
\hline Balance of the unemployment benefit system & & s. e.** \\
\hline before* & $\$ 1605$ & $(9.51)$ \\
\hline Mechanical cost change & $\$ 119$ & $(2.21)$ \\
\hline Change in benefit spending because faster reemployment & $-\$ 57$ & (12.86) \\
\hline Change in UI contribution because more time in work & $-\$ 8$ & $(1.66)$ \\
\hline after* & $\$ 1662$ & $(9.91)$ \\
\hline Net increase in UI cost & $\$ 54$ & $(15.03)$ \\
\hline Net gain in tax revenue & & \\
\hline Taxes and contributions paid by the worker because more time in work & $\$ 38$ & (8.14) \\
\hline Contributions paid by the firm because more time in work & $\$ 52$ & $(11.12)$ \\
\hline Change in government revenue & $\$ 90$ & (19.07) \\
\hline (Net gain in tax revenue - Net increase in UI cost) & $\$ 36$ & $(33.75)$ \\
\hline
\end{tabular}

*in the 1 st year after UI claimed ${ }^{* *}$ bootstrapped standard errors in parenthesis

Note: This table shows the effect of the reform on the government budget. We decompose the effect of the reform into different components based on equation 4 (see the text for details). Bootstrapped standard errors in parentheses are reported in the right column. 


\section{Figures}

Figure 1: Benefit Schedule Before and After the Reform

\section{Benefit schedule before and after the reform (age} below 50, earn above HUF114,000, \$500)

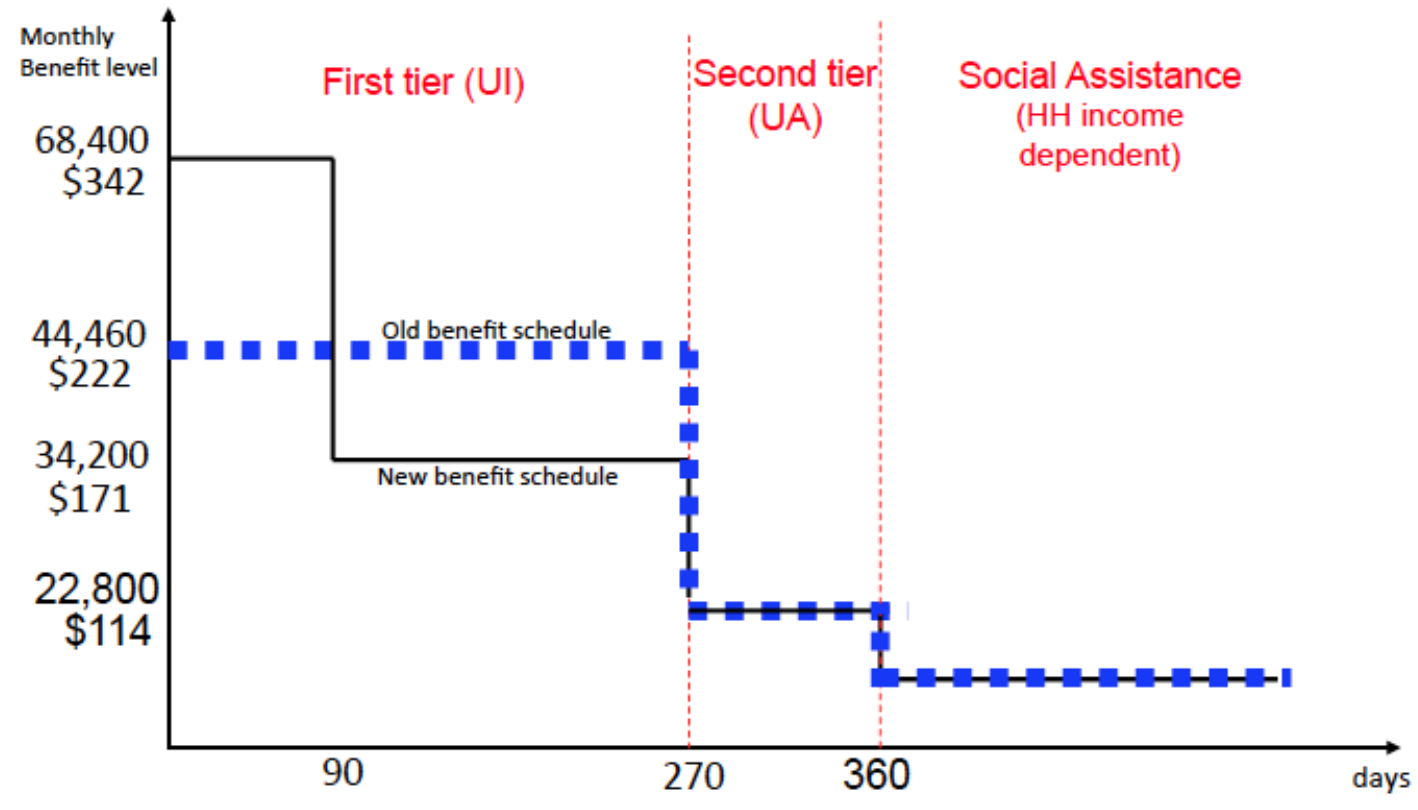

Eligible for 270 days, base salary is higher than $114,000 \mathrm{HUF}$

The figure shows the benefit schedule if UI is claimed on October 31, 2005 (old benefit schedule, dashed blue line) and the benefit schedule if UI is claimed on November 1st, 2005 (new benefit schedule, solid red line) for individuals who had 270 potential durations in the first-tier, were less than 50 years old and earned more than 114,000 HUF (\$570) prior to entering the UI scheme. The hypothetical benefit level is shown under social assistance. Benefit levels of social assistance depended on family income, household size and wealth and we do not observe these variables in our data. 
Figure 2: Before and After Comparison Groups

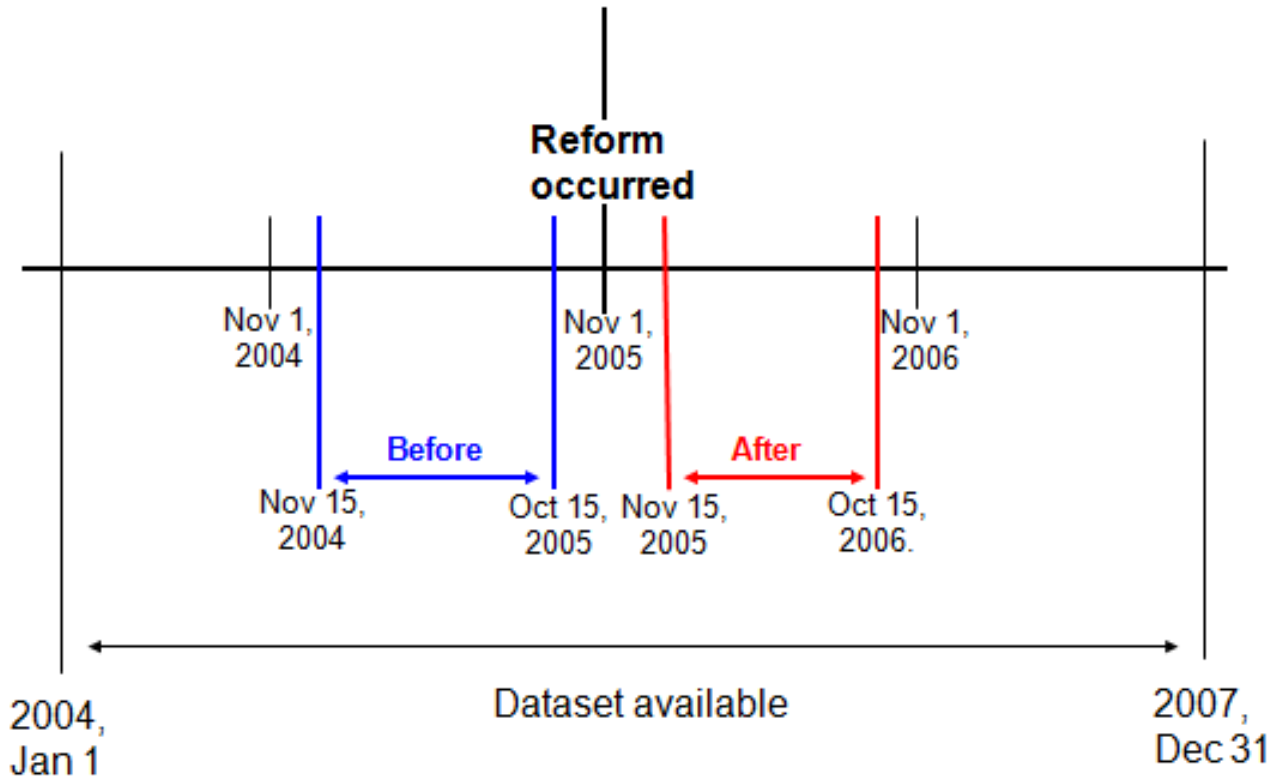

The figure shows the time frame for which we have access to administrative data on unemployment insurance records, the time of the reform and how we define the before and after periods that we use for our before-after comparison. The before sample consists of those unemployed who claimed UI between November 15th, 2004 and October 15th, 2005, and the after sample consist unemployed who claimed UI between November 15th, 2005 and October 15th, 2006. 
Figure 3: Baseline Results: Non-Employment Duration by 6-month Periods Relative to the Reform

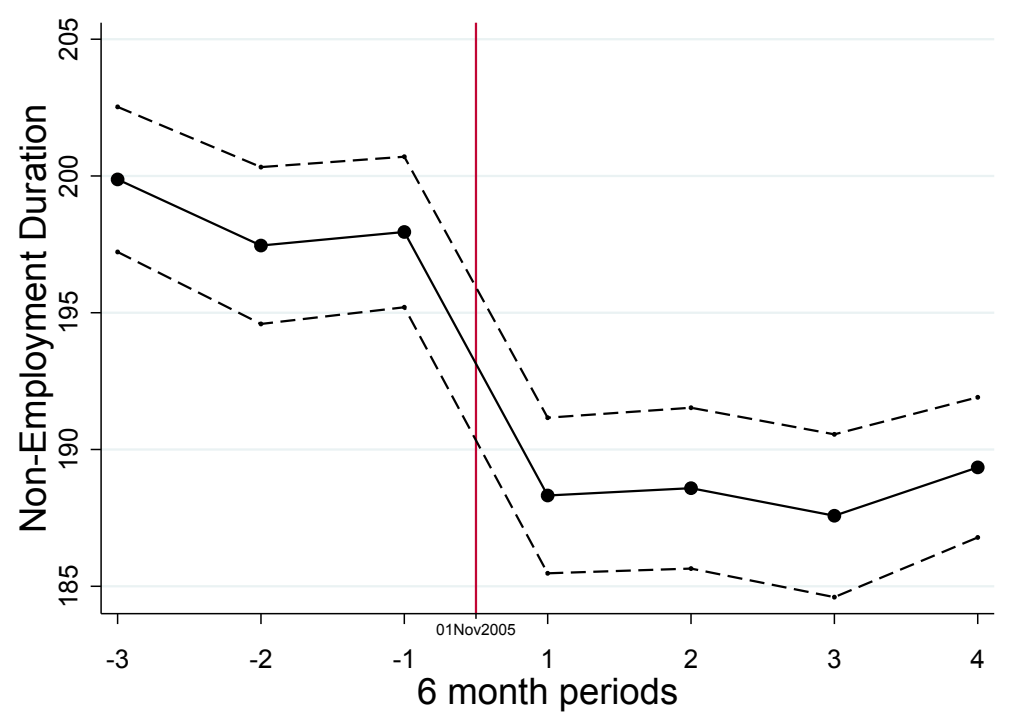

(a) No controls

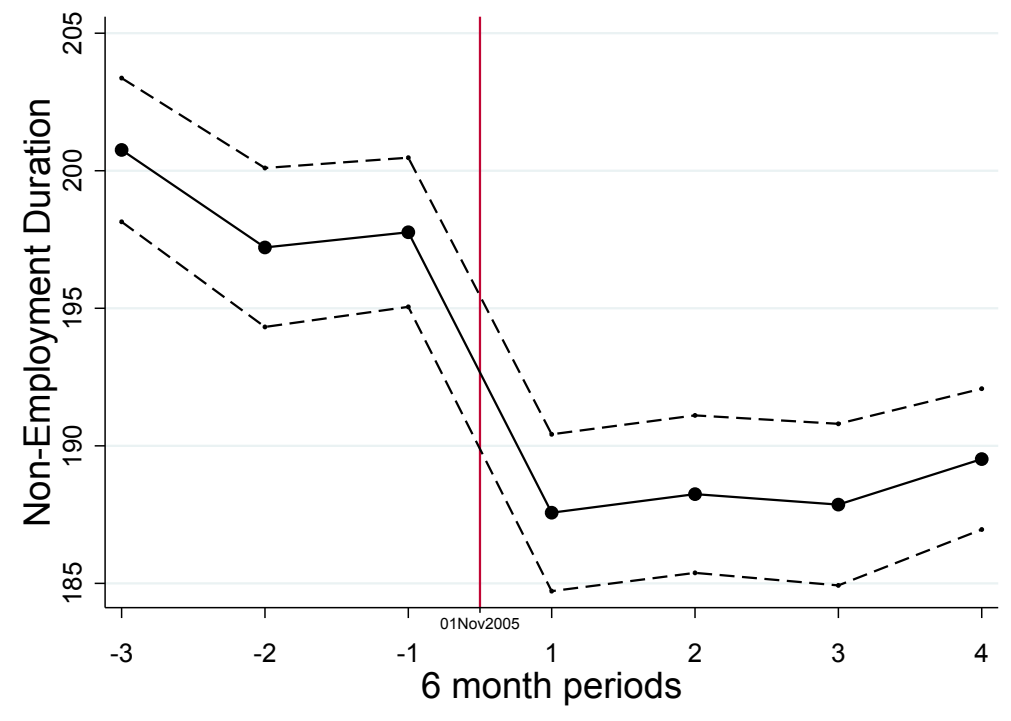

(b) With controls

The figure shows the seasonally adjusted average length of unemployment spells by 6-month periods. Panel (a) shows the unconditional averages while Panel (b) controls for sex, age, age square, waiting period (the number of days between job lost and UI claimed), the county of residence, day of the month UI claimed, education, occupation (1 digit) of the last job, and log earnings in 2002 and 2003.The figure highlights that the average length of nonemployment duration dropped immediately after the reform. The vertical red line show the timing of the benefit frontloading. . 
Figure 4: Kaplan-Meier Survival Rates Before and After the Reform

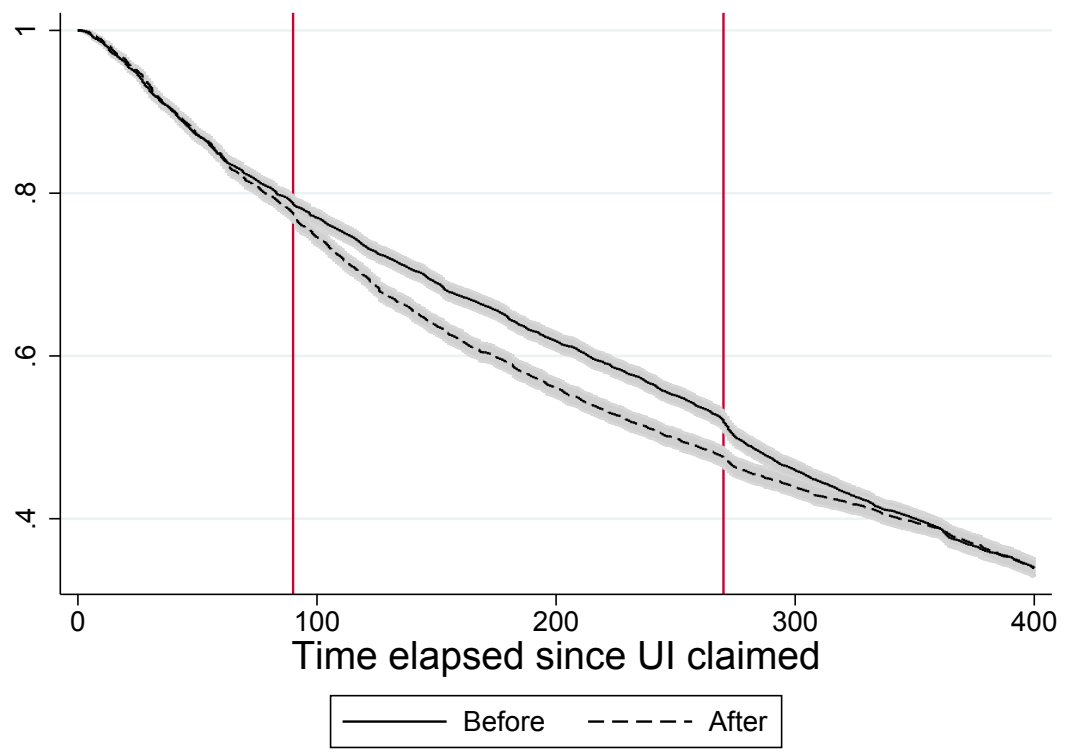

The figure shows the Kaplan-Meier survivor rates of the unemployed before and after the reform. The vertical red line shows the drop in the benefits after the reform at 90 and 270 days. The shaded area shows the confidence intervals of the survivor estimates. 
Figure 5: Job Quality: Job Tenure at the New Job Before and After the Reform

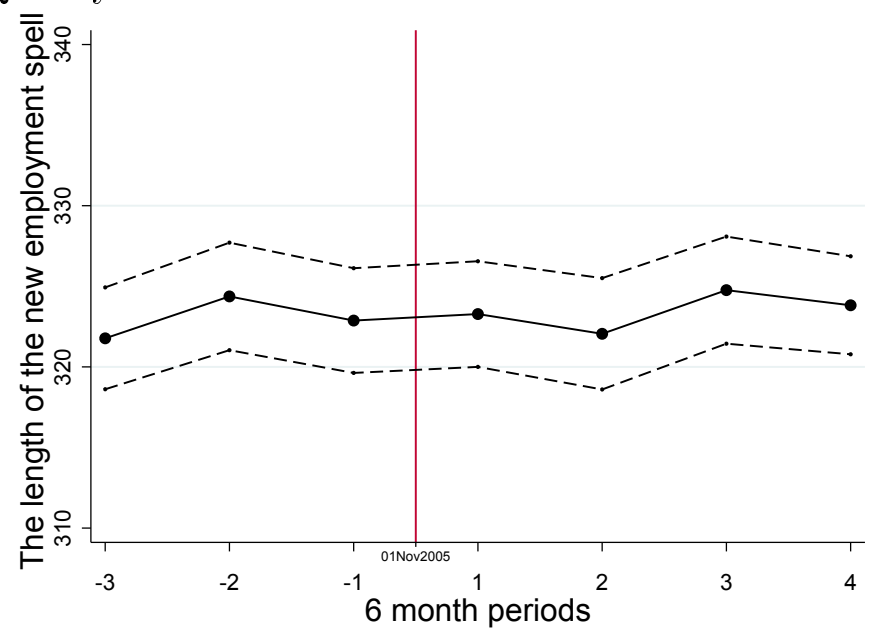

(a) No controls

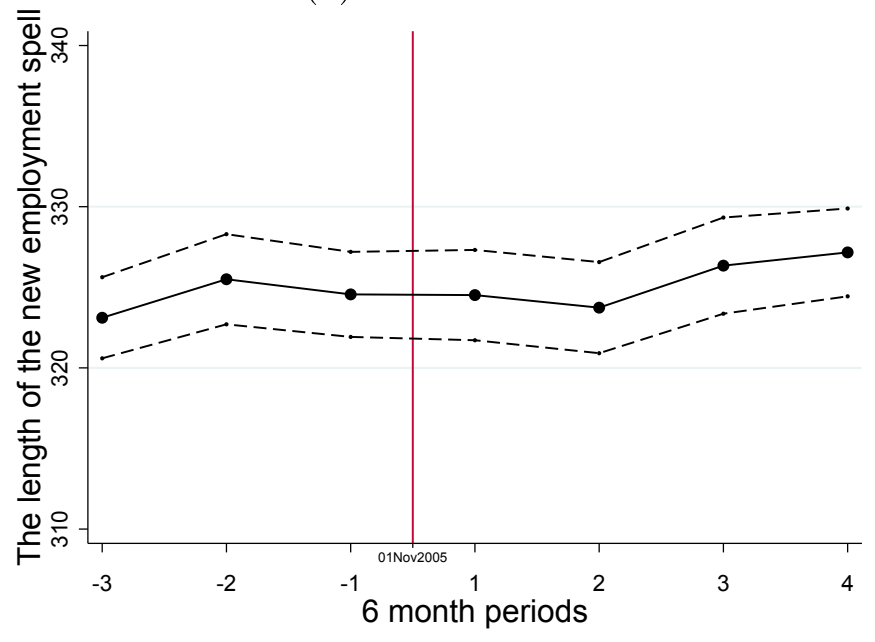

(b) With controls

The figure shows the average length of the new employment spells by 6 -month periods. The length of employment is capped at 360 days and only workers who found a job within 360 days are included in the sample. Panel (a) shows the unconditional averages while Panel (b) controls for sex, age, age square, waiting period (the number of days between job lost and UI claimed), the county of residence, day of the month UI claimed, education, occupation (1 digit) in the last job, and log earnings in 2002 and 2003. The vertical red line shows the timing of the benefit frontloading. The figure highlights that thelength of the new employment spells did not change after the reform. 
Figure 6: Job Quality: Reemployment Wages Before and After the Reform

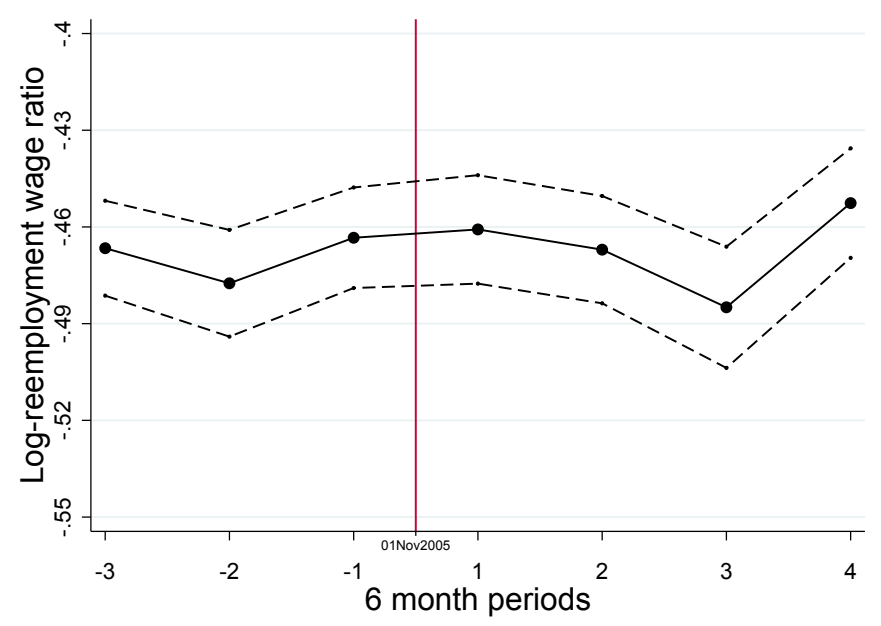

(a) No controls

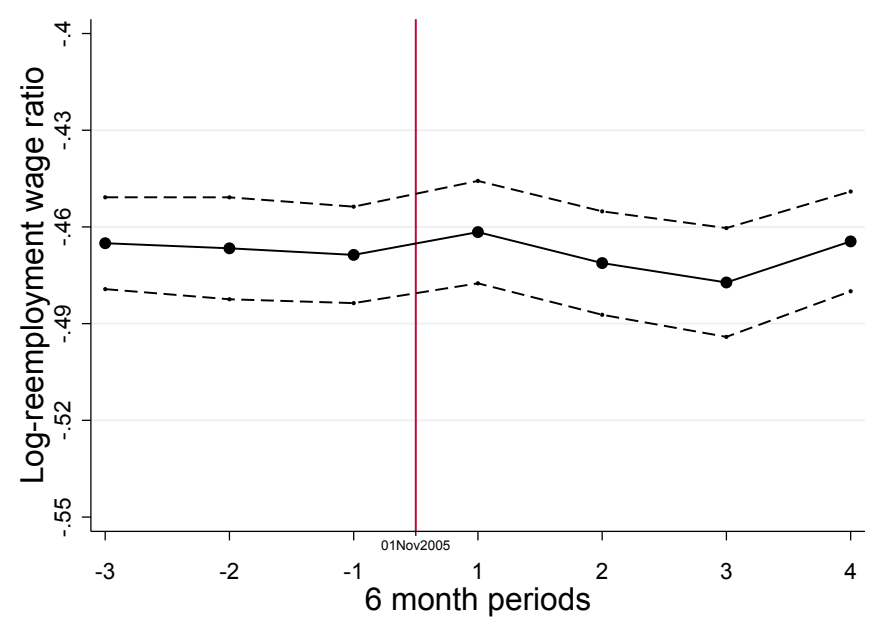

(b) With controls

The figure shows the log ratio of reemployment wage and the benefit base by 6 -month periods. Panel (a) shows the unconditional averages while Panel (b) controls for sex, age, age square, waiting period (the number of days between job lost and UI claimed), the county of residence, day of the month UI claimed, education, occupation ( 1 digit) in the last job, and log earnings in 2002 and 2003. Both regressions include linear time trends and only workers who found a job within 360 days are included in the sample. The vertical red line show the timing of the benefit frontloading. The figure highlights that reemployment wages did not change after the reform. 


\section{Figure 7: Take-up Rate of Reemployment Bonus}

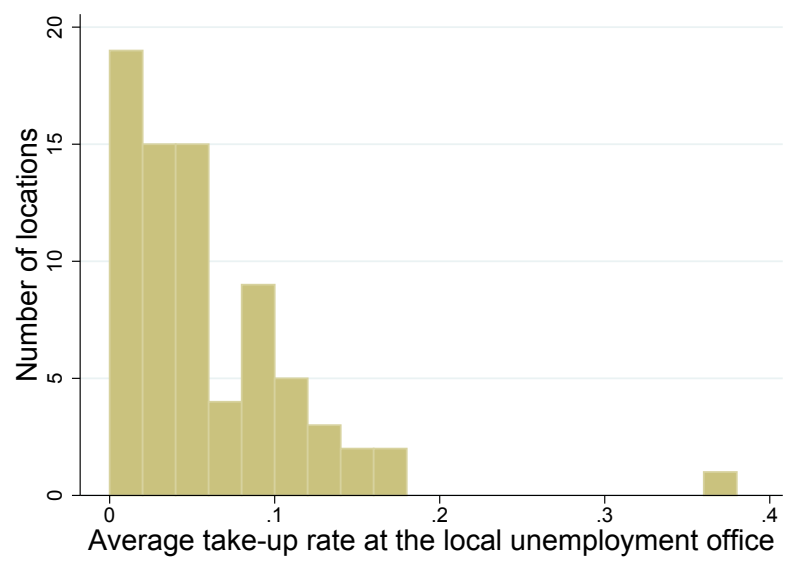

(a) Frequency distribution of the take-up rate across locations

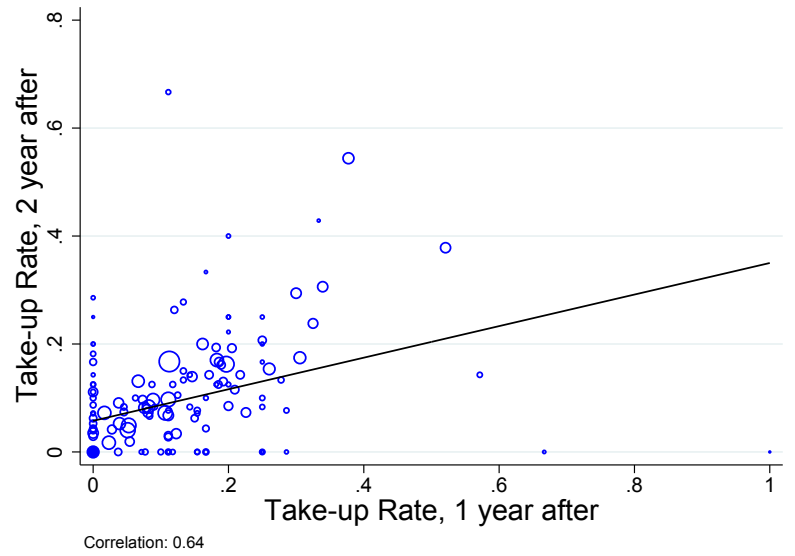

(b) Relationship between take-up rate 1 year and 2 years after the reform

Panel (a) shows the frequency distribution of local UI take-up rates . Panel (b) shows the take-up rate of reemployment bonus at local unemployment offices one year and two year after the reform. The graph highlights that the local take-up rate is persistent over time. In both panels only UI offices with at least 30 UI claimants were used. 
Figure 8: Relationship between the Composition of UI Claimants and the Take-up Rate accross Locations

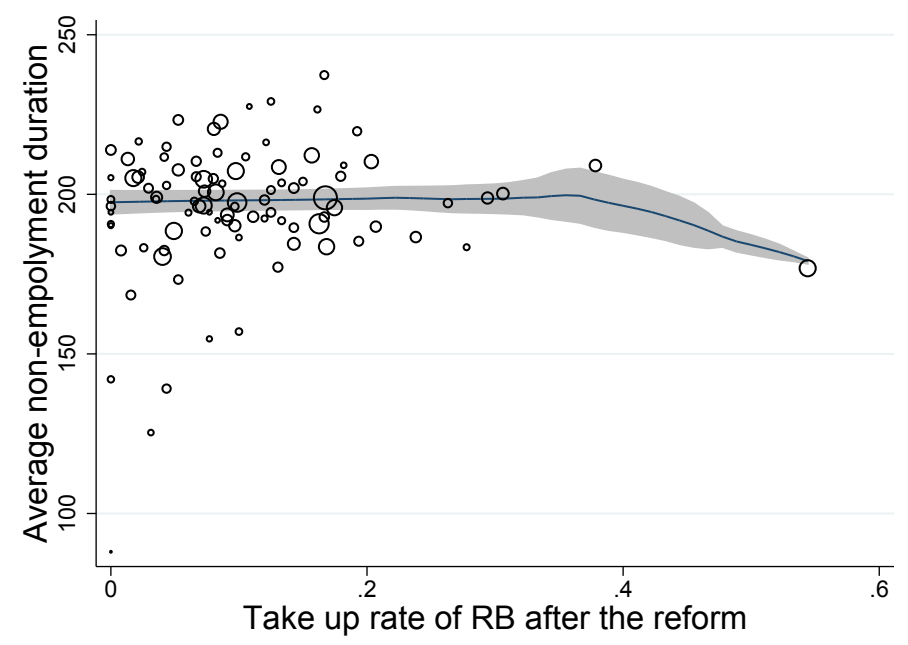

(a) Non-employment duration before the reform

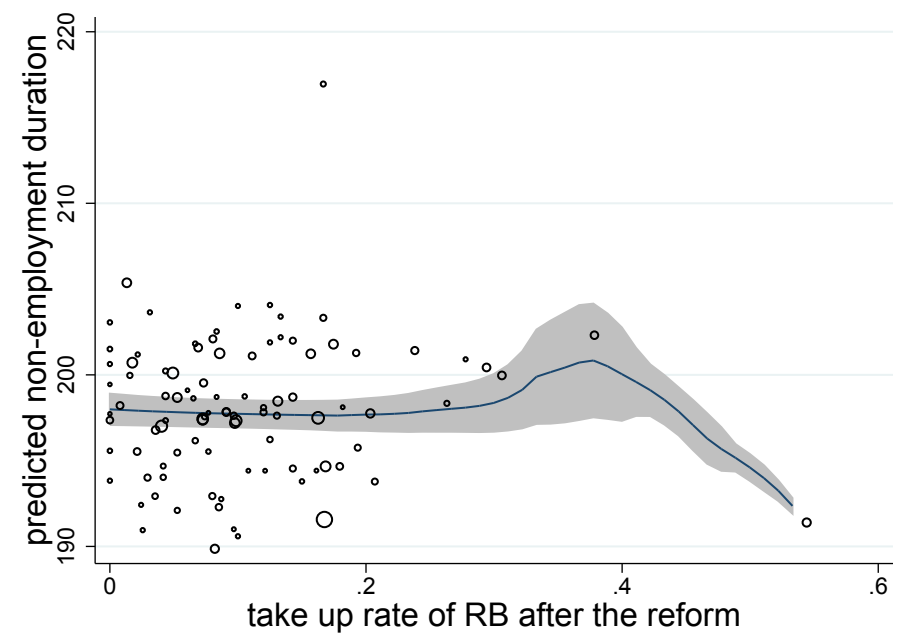

(b) Predicted non-employment duration after the reform

The figure plots the relationship between the composition of UI claimnts and the take-up rate of reemployment bonus after the reform at all UI locations. Panel (a) measures the composition of UI claimants with the average non-employment duration before the reform while panel (b) measures the composition of the unemployed by the predicted non-employment duration for those who claimed benefit after the reform. To get these predicted values we run a regression of non-employment duration on observable characteristics in the pre-reform sample and predict the average non-employment duration for the post-reform. The blue line shows the local polynomial fit weighted by the number of benefit claims before the reform. In both panels only UI offices with at least 30 UI claimants were used. The figure shows that the reemployment bonus take-up is uncorrelated with the length of non-employment before the reform. 
Figure 9: The Effect of the Reform by the Take-up Rate of the Reemployment Bonus

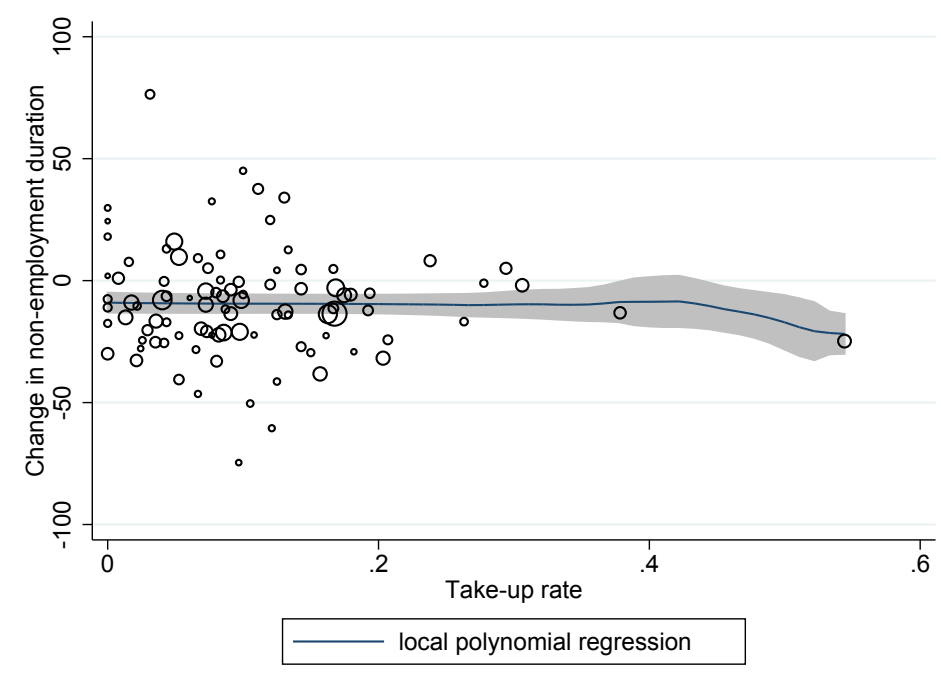

The figure plots the relationship between the before-after change in the average non-employment duration at the local UI office and the reemployment bonus take-up rate. The blue line shows the local polynomial fit weighted by the number of benefit claims before the reform. The figure shows no relationhsip between the change in nonemployment duration and the reemployment bonus take-up rate. 


\section{Appendix}

Figure A-1: Information Sheet Received by the Unemployed

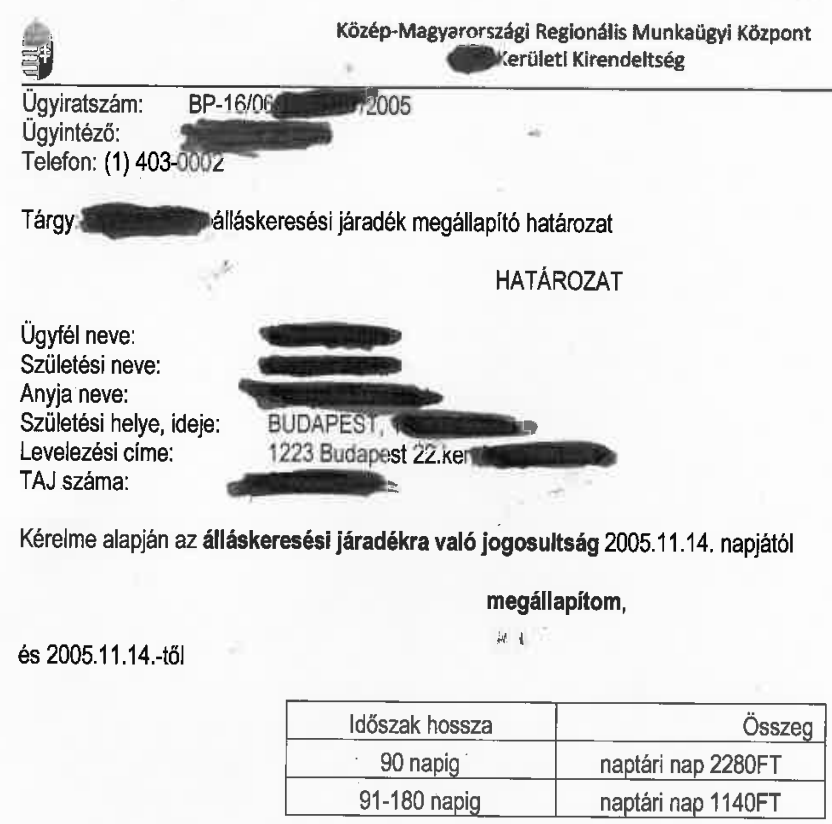

összegben való folyósítását rendelem el.

A döntés ellen a kézhezvételt követổ naptól számitott 15 napon belül a Közép-Magyarországi Regionális Munkaügyi Köszpont címzett (címe: 1082 Budapest 08. Ker. Kisfaludy utca 11), de a XVI. Kerületi Kirendeltséghez (cime 2 példányba benyújtott illetèkmentes fellebbezéssel lehet élni.

A határūzái a fellebbezésre tekintet nélkül végrehajłható.

\section{INDOKLAS}

2005.11.14. napján áláskeresési ellátás iránti kérelmet nyứtott be. Nevezett 2005.11.14. napjától álláskeresőként nyilvántartott.

A rendelkezésre álló iratokbó! megállapitottam, hogy az álláskeresővé válást megelöző öt éven belül 1728 nap munkaviszonyban töltött idövel rendelkezik.

Az álláskeresési járadék napi összegét $902500 \mathrm{Ft}$ a társadalombiztosítás ellátásaira és a magánnyugdỉjra jogosultakról, valamint e szolgáltatások fedezetéről szóló 1997. Évi LXXX. Törvény 19. §-ának (3) bekezdésében meghatározott havi átlagos munkaeröpiaci járulékalap figyelembevételével - a rendelkezésekre álló igazolások alapján - állapítottam meg.

Elözőkre tekintettel megállapítottam, hogy az álláskeresési járadék megállapitásának a foglalkoztatás elősegítésérōl és a munkanélküliek ellátásáról szóló 1991. évi IV. törvény (FIt.) 25. §(1) bekezdésében foglaltak alapján határoztam meg.

Telefon: 1/403-0002, Fax: 1/403-3433, Holnap: http://fovaros.munka.hu; http://www.afsz.hu E-mail: KMRVuqutca@lab.hu

The figure shows an example of the the first page of the personalized information sheet received by an unemployed individual when UI was claimed. According to the table in the middle, the receiver of the form was eligible for daily HUF2280 for 90 days and daily HUF1140 for another 180 days. 
Figure A-2: GDP growth and unemployment rate in Hungary

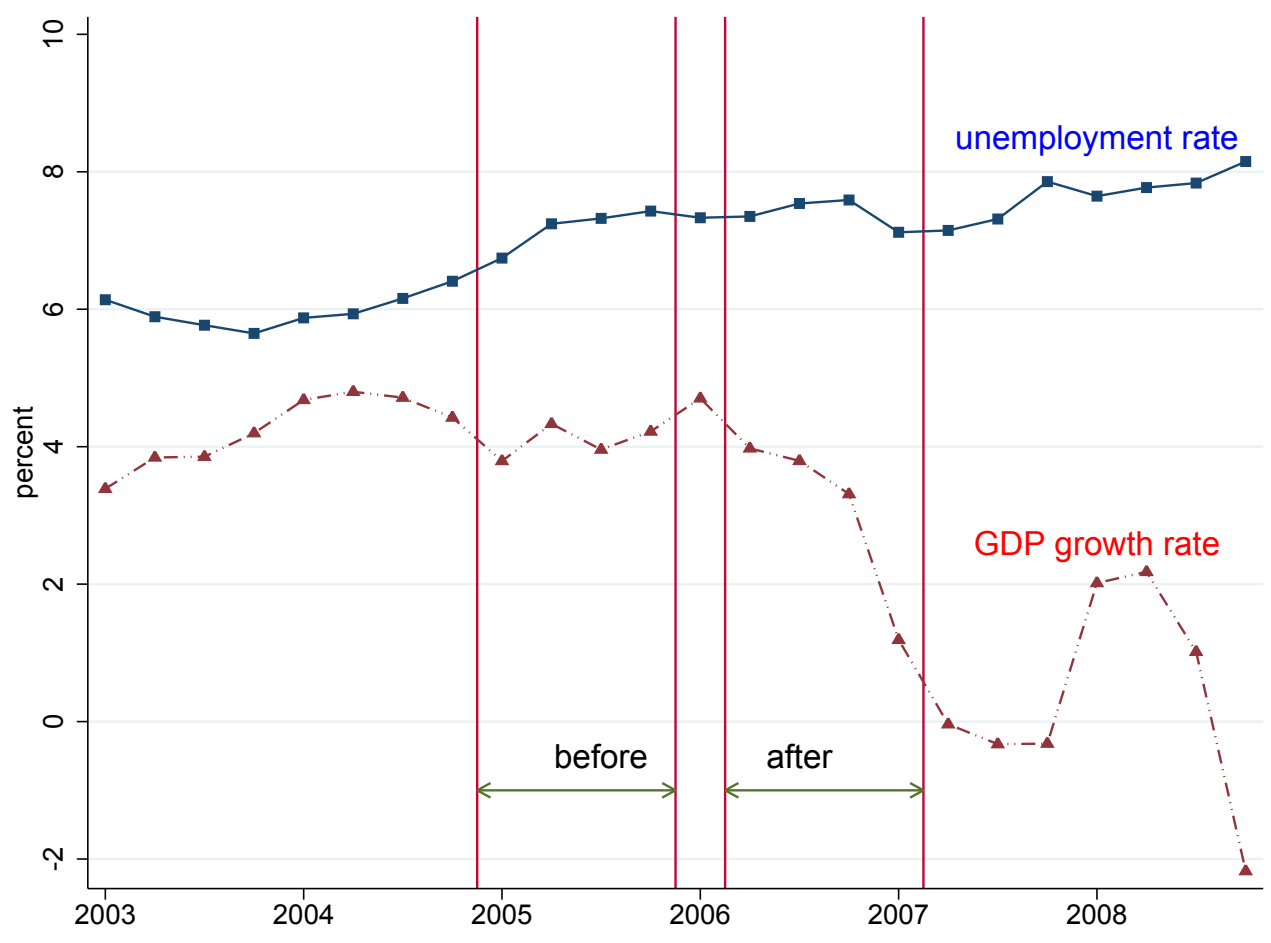

The figure shows the seasonally adjusted GDP growth rate (dashed red line) and the seasonally adjusted unemployment rate (solid blue) between 2003 and 2008 in Hungary. The major (red) vertical lines indicate the period we use for the before-after comparison. The data was obtained from the Hungarian Central Statistical Office. 
Table A-1: The effect of Frontloading by the Reemployment Bonus Take-up Rate

\begin{tabular}{|c|c|c|c|c|c|c|c|c|}
\hline \multirow[b]{2}{*}{ VARIABLES } & \multicolumn{4}{|c|}{ Non-employment duration (OLS) ${ }^{1}$} & \multicolumn{4}{|c|}{ Reemployment hazards (Cox-estimation) } \\
\hline & (1) & $(2)$ & $(3)$ & $(4)$ & $(5)$ & $(6)$ & $(7)$ & $(8)$ \\
\hline after & $\begin{array}{c}-9.50^{* * *} \\
(1.72)\end{array}$ & $\begin{array}{c}-8.67^{* * *} \\
(2.61)\end{array}$ & $\begin{array}{c}-10.29^{* * *} \\
(1.70)\end{array}$ & $\begin{array}{c}-8.74^{* * *} \\
(2.55)\end{array}$ & $\begin{array}{c}0.143^{* * *} \\
(0.028)\end{array}$ & $\begin{array}{c}0.132^{* * *} \\
(0.041)\end{array}$ & $\begin{array}{c}0.164^{* * *} \\
(0.027)\end{array}$ & $\begin{array}{c}0.140^{* * *} \\
(0.038)\end{array}$ \\
\hline take-up rate & & $\begin{array}{l}-0.135 \\
(0.193)\end{array}$ & & & & $\begin{array}{c}0.002 \\
(0.003)\end{array}$ & & \\
\hline take-up rate*after & & $\begin{array}{c}-0.0800 \\
(0.136)\end{array}$ & & $\begin{array}{l}-0.133 \\
(0.134)\end{array}$ & & $\begin{array}{c}0.001 \\
(0.002)\end{array}$ & & $\begin{array}{c}0.002 \\
(0.002)\end{array}$ \\
\hline controls & no & no & yes & yes & no & no & yes & yes \\
\hline location FE & no & no & yes & yes & no & no & yes & yes \\
\hline Observations & 13,011 & 13,011 & 13,011 & 13,011 & 13,011 & 13,011 & 13,011 & 13,011 \\
\hline R-squared & 0.002 & 0.042 & 0.003 & 0.043 & & & & \\
\hline
\end{tabular}

Clustered standard errors by UI take-up locations in parentheses

${ }^{1}$ Capped at 270 days.

$* * * \mathrm{p}<0.01,{ }^{* *} \mathrm{p}<0.05, * \mathrm{p}<0.1$

Note: This table shows the effect of the reform on non-employment duration by the local reemployment bonus take-up rate. The sample in all columns includes those unemployed individuals who claimed benefit in a UI office that has had at least $30 \mathrm{RB}$ claimants in our sample. Column 1, 3, 5 and 7 show the baseline results for this particular sample. Column 2 and 4 estimate equation 3 and Column 6 and 8 estimate a Cox proportional hazard model. We use continuous measure of take-up rate instead of using the high take-up rate dummy variable as in Table 5. The length of non-employment is capped at 270 days in all columns. The control variables are sex, age, age square, waiting period (the number of days between job lost and UI claimed), the county of residence, day of the month UI claimed, education, occupation (1 digit) in the last job, log earnings in 2002 and 2003. The location fixed effects control for the local UI office where the unemployed claimed the benefit. Standard errors in parentheses are clustered at the local UI office level. 


\section{A.1 The Effect of the Reform on the Budget}

Table 6 summarizes the effect on the budget. We use equation 4 . The $b_{t}^{\text {post }}$ and $b_{t}^{\text {pre }}$ are the daily pre- and post benefits shown on Figure $1 . S_{t}^{\text {post }}$ and $S_{t}^{\text {pre }}$ are the daily pre- and post- survival rates shown in Figure 4. The average monthly gross reemployment wage was $\$ 509$.

The following items are paid based on these gross earnings:

1. Unemployment insurance contributions. The UI contribution was $4.5 \%$ of the gross wage and paid directly into the budget of the unemployment benefit system. Given that the behavioral effect of the reform was around 10 days, the additional revenue of the benefit budget was around $\$ 509 *(10 / 30) * 4.5 \%)$.

2. Personal Income Tax. The income taxes were based on monthly earnings. The tax rate below the minimum wage $(\$ 285)$ was 0 , while above the minimum wage it was 18 percent. This means that around $(\$ 509-\$ 285) *(10 / 30) * 18 \%=\$ 13.4$ was paid in taxes.

3. Health insurance contribution. The health insurance contribution was a fixed $\$ 9.75$ per month. The additional revenue effect of that item was around $(10 / 30) * \$ 9.75=3.25$

4. Social security contribution (employee part). The social security contribution was 12.5 percent of the gross wage, and so the sum of taxes paid by the workers were around $\$ 509 *(10 / 30) * 12.5 \%=\$ 21.2$

5. Social security contribution (employer part). Firms also needs to pay social security contributions which is $30 \%$ of the gross wage so the contributions paid by the firm were around $\$ 509 *(10 / 30) * 30 \%=\$ 50.9$ 


\section{A.2 Proof of Proposition 1}

Proposition 1. Suppose that the unemployment benefit is increased by $\widetilde{\triangle b}$ in the first $N$ periods and decreased by $\Delta b$ afterwards, while the total benefit that can be collected throughout the unemployment spell remained constant, formally,

$$
\sum_{k=0}^{N} \widetilde{\triangle b}+\sum_{k=N+1}^{T} \Delta b=\sum_{k=1}^{T} \Delta b_{k}=0
$$

Then the effect of benefit change on the value of unemployment at the beginning of the UI spell is determined by the following formula:

$$
\begin{aligned}
& \triangle V_{0}^{U}\left(A_{0}\right)=\underbrace{u^{\prime}\left(c_{0}^{u *}\right) \Delta b_{0}+\sum_{k=1}^{N} \delta^{k} \prod_{i=1}^{k}\left(1-s_{i}^{*}\right) u^{\prime}\left(c_{k}^{u *}\right) \Delta b_{k}} \quad \underbrace{-\sum \delta^{k} v^{\prime}(G) \triangle G} \\
& \text { welfare effect caused by } \\
& \text { change in the benefit } \\
& \geq 0 \\
& \text { welfare effect caused by } \\
& \text { change in public spending } \\
& \lesseqgtr 0
\end{aligned}
$$

The first part of this formula, welfare effect caused by change in the benefit, is always nonnegative, and it only becomes positive if optimal search $s_{t}^{*}$ is positive for at least one period throughout the unemployment spell or if the interest rate, $r$, is positive. The second part of this formula, the welfare effect caused by change in public spending, can be positive, negative or zero depending on the sign of $\triangle G$. Moreover, $\triangle G$ will be determined by the following equation.

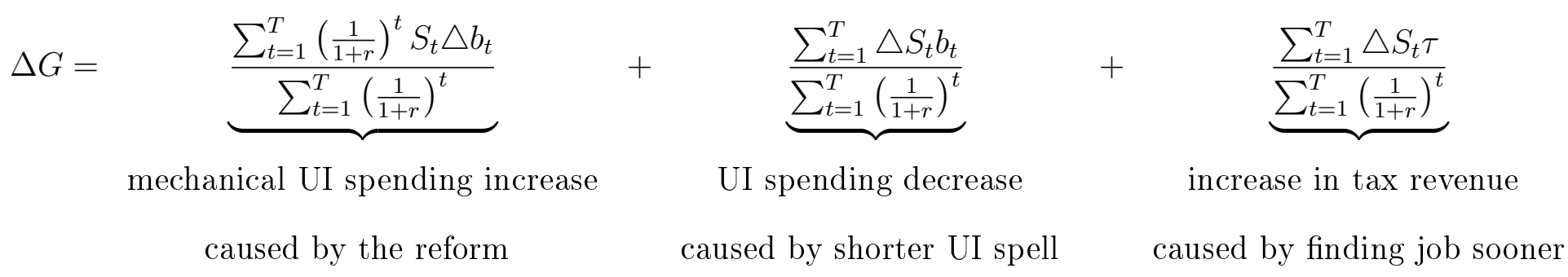


Proof:

The value of unemployment is defined by the following equation:

$$
V_{t}^{U}\left(A_{t}\right)=u\left(c_{i}^{u *}\right)-c\left(s_{t}^{*}\right)+v(G)+\delta\left[s_{t} V_{t+1}^{E}\left(A_{t+1}^{*}\right)+\left(1-s_{t}\right) V_{t+1}^{U}\left(A_{t+1}^{*}\right)\right]
$$

Based on this the value of unemployment in period 0 can be rewritten as

$$
V_{0}^{U}\left(A_{0}\right)=\sum_{k=0}^{T} \delta^{k} v(G)+u\left(c_{0}^{u *}\right)-c\left(s_{0}^{*}\right)+\sum_{k=1}^{T} \delta^{k} \prod_{i=1}^{k}\left(1-s_{i}^{*}\right)\left[u\left(c_{k}^{u *}\right)-c\left(s_{k}^{*}\right)\right]+\sum_{k=1}^{T} \delta^{k} \prod_{i=1}^{k-1}\left(1-s_{i}^{*}\right) s_{k}^{*} V_{k}^{E}\left(A_{t+1}^{*}\right)
$$

Now we look at the change in benefits described by equation 6 . By the envelop theorem the indirect effect on the value function will be second order, and so the effect of benefit change on the value function will be the following:

$$
\triangle V_{0}^{U}\left(A_{0}\right)=\underbrace{u^{\prime}\left(c_{0}^{u *}\right) \Delta b_{0}+\sum_{k=1}^{N} \delta^{k} \prod_{i=1}^{k}\left(1-s_{i}^{*}\right) u^{\prime}\left(c_{k}^{u *}\right) \Delta b_{k}}_{\begin{array}{c}
\text { welfare effect caused by } \\
\text { change in the benefit } \\
\geq 0
\end{array}} \underbrace{\sum 0}_{\begin{array}{c}
\text { welfare effect caused by } \\
\text { change in public spending } \\
\vdots 0
\end{array}}
$$

As we show next, the first term is always positive, while the second term can be positive or negative depending on the sign of $\triangle G$. We will provide the expression for $\triangle G$ later.

To show that the welfare effect caused by the benefit change is non-negative, we stipulate that the optimal consumption path must satisfy the usual Euler equation:

$$
u^{\prime}\left(c_{t}^{u *}\right) \geq \delta(1+r)\left[s_{t}^{*} \frac{\partial V_{t+1}^{E}\left(A_{t+1}^{*}\right)}{\partial A_{t+1}}+\left(1-s_{t}^{*}\right) u^{\prime}\left(c_{t+1}^{u *}\right)\right]
$$


This equation can be easily derived from the FOC of the value function with respect to $A_{t+1}$ and from the envelop theorem that indicates that $\frac{\partial V_{t+1}^{U}\left(A_{t+1}^{*}\right)}{\partial A_{t+1}}=u^{\prime}\left(c_{t+1}^{u *}\right)$. This equation holds for equality in the absence of borrowing constraints while in the presence of binding borrowing constraints the left hand side is strictly greater than the right hand side.

Given that $\frac{\partial V_{t+1}^{E}\left(A_{t+1}^{*}\right)}{\partial A_{t+1}}>0, s_{t}^{*} \geq 0$, and $r \geq 0$, the Euler equation implies that $u^{\prime}\left(c_{t}^{u *}\right) \geq$ $\delta\left(1-s_{t}^{*}\right) u^{\prime}\left(c_{t+1}^{u *}\right)$ for all $t$ and this inequality holds strictly if $s_{t}^{*}>0$ or $1+r>1$. This equation also implies that $\delta^{t} \prod_{i=1}^{t}\left(1-s_{t}^{*}\right) u^{\prime}\left(c_{t}^{u *}\right) \geq \delta^{T} \prod_{i=1}^{T}\left(1-s_{t}^{*}\right) u^{\prime}\left(c_{T}^{u *}\right)$ for all $t$. Therefore,

$$
u^{\prime}\left(c_{0}^{u *}\right) \Delta b_{0}+\sum_{k=1}^{T} \delta^{k} \prod_{i=1}^{k}\left(1-s_{i}^{*}\right) u^{\prime}\left(c_{k}^{u *}\right) \Delta b_{k} \geq \prod_{i=1}^{T}\left(1-s_{i}^{*}\right) u^{\prime}\left(c_{T}^{u *}\right) \sum_{k=1}^{T} \Delta b_{k}
$$

and whenever $s_{t}^{*}>0$ for at least one period or $r>0$, this inequality holds strictly. Moreover, given that equation $6 \sum_{k=1}^{T} \Delta b_{k}=0$, this inequality implies that the first part of equation 7 is positive:

$$
u^{\prime}\left(c_{0}^{u *}\right) \Delta b_{0}+\sum_{k=1}^{N} \delta^{k} \prod_{i=1}^{k}\left(1-s_{i}^{*}\right) u^{\prime}\left(c_{k}^{u *}\right) \Delta b_{k} \geq 0
$$

and the inequality holds strictly if $s_{t}^{*}>0$ for at least one period or if $r>0$.

Now we derive the expression for $\Delta G$. By total differentiating the government budget we get the following expression:

$$
0=\sum_{t=1}^{T}\left(\frac{1}{1+r}\right)^{t} \Delta G+\sum_{t=1}^{T}\left(\frac{1}{1+r}\right)^{t} \Delta S_{t} b_{t}+\sum_{t=1}^{T}\left(\frac{1}{1+r}\right)^{t} S_{t} \Delta b_{t}+\sum_{t=1}^{T}\left(\frac{1}{1+r}\right)^{t} \Delta S_{t} \tau w .
$$

where we specify that taxes and deficit are kept constant. This leads to the expression in the 
proposition:

$$
\Delta G=\underbrace{\frac{\sum_{t=1}^{T}\left(\frac{1}{1+r}\right)^{t} S_{t} \triangle b_{t}}{\sum_{t=1}^{T}\left(\frac{1}{1+r}\right)^{t}}}+\underbrace{\frac{\sum_{t=1}^{T} \triangle S_{t} b_{t}}{\sum_{t=1}^{T}\left(\frac{1}{1+r}\right)^{t}}}+\underbrace{\frac{\sum_{t=1}^{T} \triangle S_{t} \tau}{\sum_{t=1}^{T}\left(\frac{1}{1+r}\right)^{t}}}
$$

mechanical UI spending increase

caused by the reform
UI spending decrease

caused by shorter UI spell increase in tax revenue

caused by fining job sooneer 